\title{
MASTER
}

DOE/NASA CONTRACTOR

DOE /NASA CR-161238

REPORT

\section{SOLAR ENERGY SYSTEM INSTALLED AT MOUNT RUSHMORE NATIONAL VISITOR CENTER IN KEYSTONE, SOUTH DAKOTA}

Prepared from documents furnished by

South Dakota School of Mines and Technology

Rapid City, South Dakota 57701

Under DOE Contract EX-76-C-01-2399

Monitored by

National Aeronautics and Space Administration

George C. Marshall Space Flight Center, Alabama 35812

For the U. S. Department of Energy

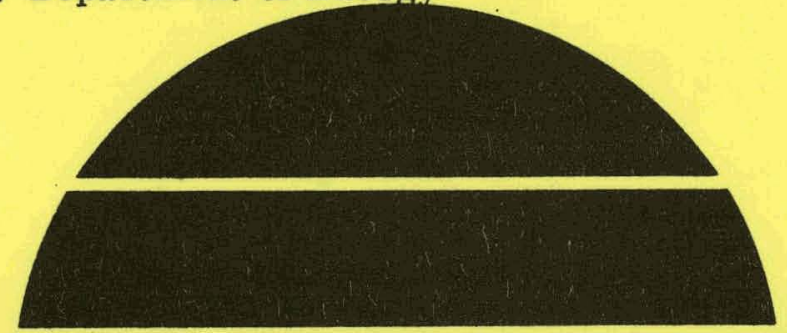

\section{U.S. Department of Energy}




\section{DISCLAIMER}

This report was prepared as an account of work sponsored by an agency of the United States Government. Neither the United States Government nor any agency Thereof, nor any of their employees, makes any warranty, express or implied, or assumes any legal liability or responsibility for the accuracy, completeness, or usefulness of any information, apparatus, product, or process disclosed, or represents that its use would not infringe privately owned rights. Reference herein to any specific commercial product, process, or service by trade name, trademark, manufacturer, or otherwise does not necessarily constitute or imply its endorsement, recommendation, or favoring by the United States Government or any agency thereof. The views and opinions of authors expressed herein do not necessarily state or reflect those of the United States Government or any agency thereof. 


\section{DISCLAIMER}

Portions of this document may be illegible in electronic image products. Images are produced from the best available original document. 
TECHNICAL REPORT ST ANDARD TITLE PAGE

\begin{tabular}{|c|c|}
\hline \begin{tabular}{l|l} 
1. REPORT NO. & 2. GOVERNMENT ACCESSION NO. \\
DOE/NASA CR-161238 &
\end{tabular} & 3. RECIPIENT'S CATALOG NO. \\
\hline \multirow{2}{*}{$\begin{array}{l}\text { 4. TITLE AND SUBTITLE } \\
\text { Solar Energy System Installed at Mount Rushmore National } \\
\text { Visitor Center in Keystone, S. D. }\end{array}$} & $\begin{array}{l}\text { 5. REPORT DATE } \\
\text { June } 1979\end{array}$ \\
\hline & 6. PERFORMING ORGANIZATION CQDE \\
\hline 7. AUTHOR(S) & 8. PERFORMING ORGANIZATION REPORT \# \\
\hline \multirow{3}{*}{$\begin{array}{l}\text { 9. PERFORMING ORGANIZATION NAME AND ADDRESS } \\
\text { South Dakota School of Mines and Technology } \\
\text { Rapid City, S. D. } 57701\end{array}$} & 10. WORK UNIT. NO. \\
\hline & $\begin{array}{l}\text { 11. CONTRACT OR GRANT NO. } \\
\text { DOE EX-76-C-01-2399 }\end{array}$ \\
\hline & \multirow{2}{*}{$\begin{array}{l}\text { 13. TYPE OF REPORi \& PERIOD COVERED } \\
\text { Contractor Report }\end{array}$} \\
\hline \multirow{2}{*}{$\begin{array}{l}\text { 12. SPONSORING AGENCY NAME AND ADDRESS } \\
\text { National Aeronautics and Space Administration } \\
\text { Washington, D. C. } 20546\end{array}$} & \\
\hline & 1.1. SPONSORING AGENCY CODE \\
\hline
\end{tabular}

15. SUPPLEMENTARY NOTES

This work was done under the technical management of Mr. Val Fogle, George C. Marshall. Space Flight Center, Alabama.

18. ABSTRACT

This final report provides information on the system description, the design and installation of the solar energy system installed at the Mount Rushmore Visitor Center. The system is designed to furnish about 45 percent of the heating for the total facility and about 53 percent partial cooling for the 2000 square-foot observatory. The report contains such items as Acceptance Test Data, a complete set of as-built drawings, system performance data, problems, pictures, and other pertinent material.

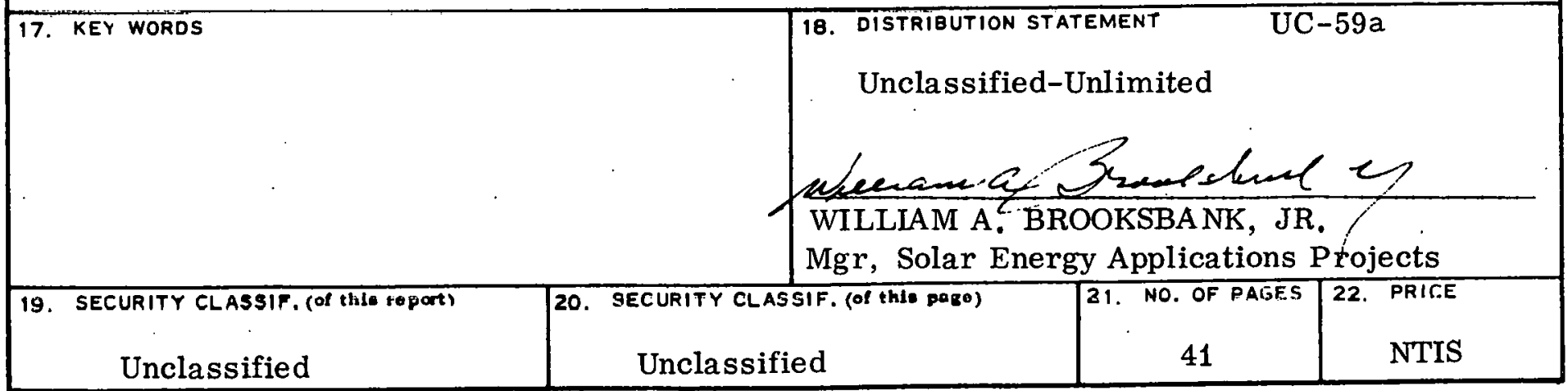


THIS PAGE

\section{WAS INTENTIONALLY LEFT BLANK}


FINAL REPORT OUTLINE

\section{Table of Contents}

1. Narrative Description of solar energy system and building. 1

2 . Acceptance Test Data 5

3 . Complete set of as-built drawings 11

4 - Operation and Maintenance Manuals (references) 20

5 . Pictures of final installation 20

6 . Predicted System Performance Data 30

7 . Major problems encountered and resolutions thereto 37

8 . Lessons learned and recommendations 38

9 . Statements verifying the solar system 39

This report was prepared as an account of work sponsored by the United States Government. Neither the United States nor the United States Department of Energy, nor any of their employees, nor any of their contractors, subcontractors, or their employees, makes any wasranty, express or implied, or assumes any legal liability or responsibility for the accuracy, completeness

or usefulness of any information, apparatus, product or

process disclosed, or represents that its use would not

infringe privately owned rights. 
1. Narrative Description of solar energy system and building INTRODUCTION

This project is a solar retrofit project of Mount Rushmore National Memorial Visitor Center at Keystone, SD, where over two million tourists visit each year. The Visitor Center has a total space of approximately 6,000 sq. ft. The solar system is designed to furnish approximately $45 \%$ of heating for the total facility, and approximately $53 \%$ partial cooling of the 2,000 sq. ft. observatory room. There are a total of 112 panels of Lennox 1 iquid circulated collectors, each $3 \mathrm{ft}$ by $6 \mathrm{ft}$ in dimension, with a gross surface of approximately $2,000 \mathrm{sq} . \mathrm{ft}$. Collector panels are mounted in $5 \frac{1}{2}$ rows on the roof of the Visitor Center owned by National Park Service of the Department of Interior. The building was designed by the Spitznagel Partners, Inc. The project consists of four team members with South Dakota School of Mines and Technology as program manager; the Spitznagel Partners, Inc. as construction manager and designer; Honeywell as a collector supplier; and the Mount Rushmore National Memorial as the owner. DESIGN PHILOSOPHY

The first design decision was to install collectors which used liquid rather than air as the heat transfer fluid. There were three factors which indicated that this was the best choice: (1) A liquid medium would integrate easily with the existing system by simply installing a heating coil in the furnace air duct. The liquid could be circulated directly from the collectors to the heating coil for optimum transfer without additional blowers. (2) There is a need for extra air-conditioning in the observatory room which could be met by solar activated lithium bromide absorption refrigeration units. Air collectors do not produce high enough temperatures to activate these units. (3) The limited space to mount the collector array required 
collectors with high efficiency and air collectors are generally less efficient than liquid collectors.

Some of the more important design decisions were determined according to the following conditions: (1) The collector area (active area of 1720 sq. ft.) is the maximum which can be fit on the roof and allow enough spacing to avoid shading (5\% of total in December). This is also based on the actual total fuel consumed in FY 1975 or 8,721 gallons of No. 2 oil, assuming a heating value of 140,000 BTU per gallon and a furnace efficlency of $50 \%$ due to the age of the furnace and an al,titude of about one $m+1 e$, the total annual heating load of about $6.1 \times 10^{8}$ BTU's is determined. (2) The three 3-ton Arkla units are the maximum number which can be operated with the given collectors. (3) The 3,000 gal. storage tank is a compromise between performance and available space. (4) The solar heat coil, effectiveness $=0.538$, is the largest reasonable coil which can fit into the existing furnace duct. The angle at which the collectors are placed is a combination of the orientation of the roof, a $45^{\circ}$ angle relative to the roof for ease of construction, and a need for solar collection both in winter and summer. The optimum angle for this particular application was not determined, but other simple models show that the performance is probably only $2 \%$ less at this angle than at the optimum of about $55^{\circ}$ in winter. The angles used here favor the air conditioning application. (6) The control system is designed to use solar heating or cooling first and then the current conventional system as backup. It will be possible to air condition and solar heat during the same day, even though this feature is not in the computer model for simplification.

Solar energy system calculations were based on climatological data for Rapid City supplied by the National Oceanic and Atmospheric Administration (NOAA). The climatological conditions at Mount Rushmore (25 miles southwest 
and 2,000 feet higher than Rapid City) are expected to be more favorable due to the altitude and lack of pollution in the air, making these calculations conservative.

TRNSYS system developed by the University of Wisconsin modified by South Dakota School of Mines and Technology was used to simulate the solar system. The climatological data for.1971-74 was used for the simulation model. The TRNSYS program used here should enable the user to write a workable transient simulation program with a minimal knowledge of computers. TRNSYS has built-in checks to spot obvious errors such as calling for an input from a non-existent unit, failure to specify initial conditions, etc. Other errors such as improper conversion of units, crossing the temperature with the flow rate, etc. can be very difficult to spot. In this case the user must know enough about the system to realize that the answers are nonsense, even though the computer processes the numbers without printing an error message. If the program fails to produce answers which converge within the specified tolerances in the specified number of iterations, the user has recourse to decreasing the time step, raising the tolerances or number of iterations, or sticking the control units after fewer calls in one time step. When these fail to produce convergence, then it is essential to have familiarity with FORTRAN and general knowledge of iterative techniques to trace and correct the difficulty.

The flow rate is calculated on the basis of $.3 \mathrm{gpm}$ per collector panel specified by the supplier.

The 3,000 gallon storage tank to provide reasonable heat storage for heating and reasonable period of continuous cooling is housed above the ground with three 3-ton Arkla units, heat exchanger, pumps, and all controls in a building connected to the Visitor Center on the east side. This selec- 
tion gives ease in installation of piping, storage tank and other equipment. The length of piping is minimized.

OPERATION OF THE SYSTEM

The whole system was completed in September of 1977. First the system was tested with pure water in the solar collector loop for about a week, and the system seemed to function properly and was then charged with ethelene glycol for continuous operation. The presence of air bubbles in the system was a constant problem. The pressure build-up due to the air bubbles was alleviated by frequent venting on the top of the roof. The system pressure could be in excess of $70 \mathrm{psig}$. The air venting could be as frequent as once a week.

The winter of 1977 in South Dakota was one of the severest ones experienced. The National Park Service was quite happy with the saving of many gallons of oil. The system apparently functioned well in solar heating. No major problems were detected except that the main system pump was always running for all modes of operation. Nobody knew exactly how well. the system was functioning until the early part of May of 1978 when IBM contracted Site Data Acquisition System (SDAS) to begin to produce some computer printouts. Quite a few anomalies were picked up by the SDAS such as the main system pump was running all the time; the sequence of operations was different from what was originally planned; solar and auxiliary heating have the same control setting; energy from storage is not always being taken to meet the heating load, etc.

The Arkla cooling units were started after mid-July. of 1978. The cooling system was never utilized to its full capacity due to the: fact that the control of the system was not completely under control. Adjustments and corrections are still being made by the Honeywell people. In general, most 
major anomalies have been corrected. It is expected the system will operate properly both heating and cooling in seasons to come:

SUCCESSFUL COMPONENTS OR PROCESSES

Aesthetically the Park Service people were worried that the presence of solar energy heating project might distract from the main attraction. Since the installation of the collector panels, the visitors apparently are not aware of the presence of collector panels on the roof of the building. This seems to satisfy the Park Service. Comments from people who have seen the collector panels are good. Aesthetically, they blend in very naturally with the building.

\section{Acceptance Test Data}

\section{a. ACCEPTANCE TEST PLAN}

The basic philosophy of the acceptance test plan will be simply to insure that the entire system functions as designed. The acceptance test will be primarily based on the results provided by the government's Site Data Acquisition System and its on-site monitor. Results of a minimum of one week of continuous operation are required for the acceptance test.

Referring to the attached diagram, a total of 44 sensors as shown are installed to the whole system. 8 sensors with a prefix of EP are for the measurements of electrical power consumed by pumps; 6 sensors with a prefix of $W$ for the measurements of pump flowrate of liquid; 24 . sensors with a prefix of $T$ are for temperature measurements; and 6 remaining sensors are: 4 with a prefix of RH for the measurements of humidity, 1 with a prefix of $F$ for the measurements of fuel oil flowrate, and 1 with a number of 1001 for the measurement of the total solar insolation. Results of the Site Data Acquisition System are obtained from the 44 sensors as shown in the attached diagram. 
- 1001 total imbolation

- roor oursior ame

- toor intsanal amo

a)

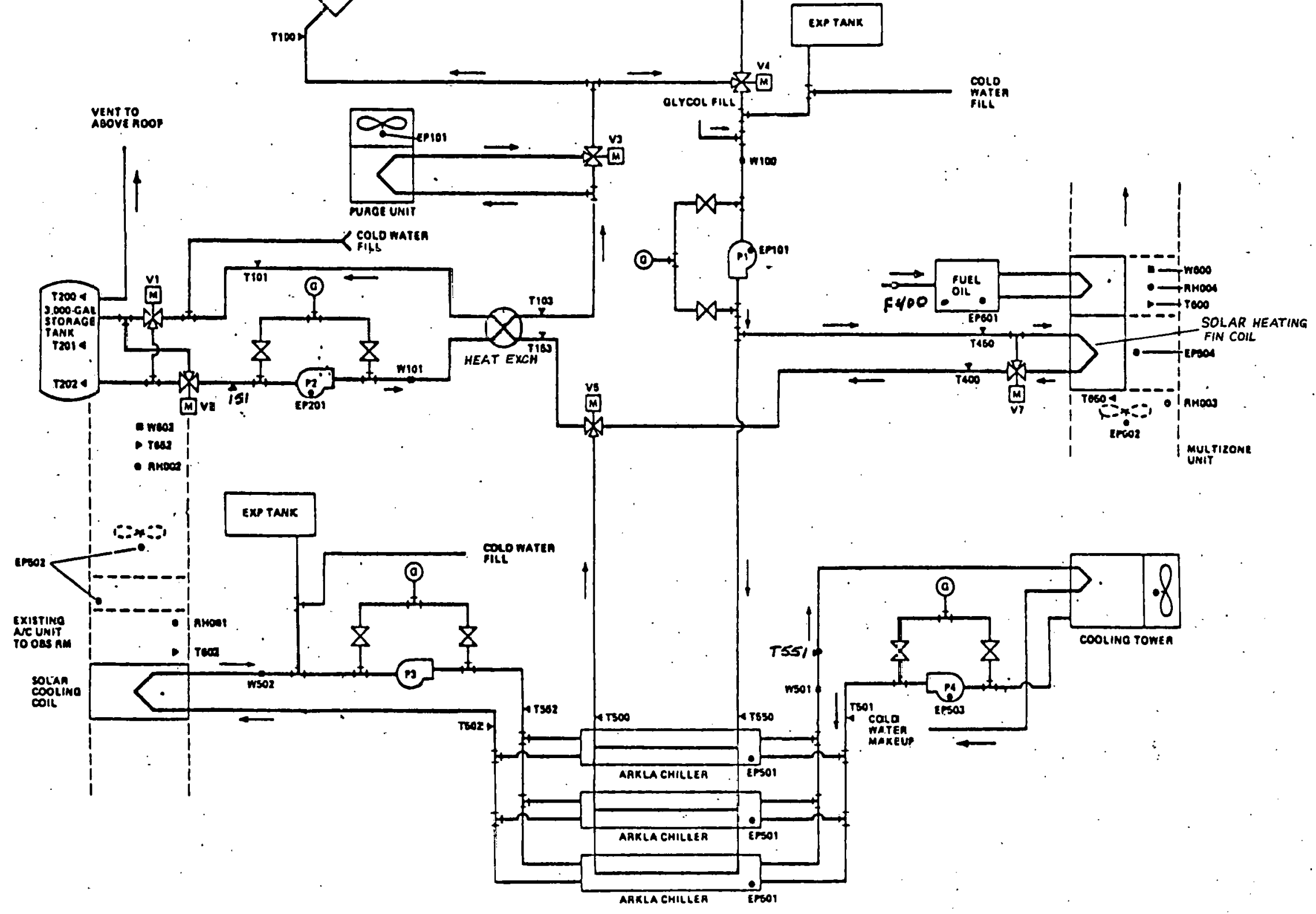

MOUNT RUSHMORE SYSTEM SCHEMATIC $(10 / 4 / 78)$ 
On a component basis, the items to be tested will be all pumps, motors, heat exchanger, coils, fans, cooling tower, solar collectors, valves, controls and sensors, and ARKLA cooling units. A general visual and physical inspection of all items including leakage and insulation free from any defect will be conducted. Tolerances for various items are to meet within $\pm 10 \%$ of the designed performance, for most of the items, as specified in the attached designed equipment schedule.

The controls will be tested according to the attached sequence of operations.

GENERAL.

Space heating and cooling is controlled by the existing space thermostats. First stage heating is provided by solar heated water directly from the collectors or from the storage tank to the solar heating coil located in the existing multizone unit. Second and third stage heating are accomplished by firing the existing burner which is sequenced through two firing stages: First stage cooling is provided by the Arkla absorption units. Second stage cooling is accomplished by sequencing the existing multi-zone unit and direct expansion unit.

\section{FIRST STAGE HEATING FROM COLLECTOR}

On a call for heat from the space thermostats and by the discharge air temperature THD, valve $V 7$ is modulated to control the hot deck temperature. Pump $P 1$ is enabled to run and valve $V 4$ is positioned $A$ to $A B$ if the collector plate temperature (TPH) is greater than $125^{\circ} \mathrm{F}$ (adjustable). A time delay will delay pump P1 shut down to prevent short cycling.

\section{FIRST STAGE HEATING FROM STORAGE}

Heating from storage is accomplished whenever energy is not available from the collectors, heating demand occurs and energy is available from storage. On a call for heat, valve $V 7$ and $V 5$ are in the heating positions. 
Valve $V 4$ is $B$ to $A B$. Pump $P 2$ and $P 1$ are enabled to run if the storage tank temperature TSD is greater than $100^{\circ} \mathrm{F}$ (adjustable). Valves $\mathrm{V} 1$ and $V 2$ are positioned $B$ to $A B$ respectively.

SECOND AND THIRD STAGE HEATING

If first stage heating cannot be satisfied from the collectors or storage as sensed by discharge air sensor THD and the space thermostat, then the existing burner will be sequenced through it's two firing stages. FIRST STAGE COOLING FROM COLLECTORS.

First stage cooling is provided by the Arkla Absorption units Al through $A 3$. On a call for cooling, valve $V 5$ is positioned $A$ to $A B$ and valve $V 7$ is positioned $B$ to $A B$. If solar heat is available from the collectors, which is sensed by collector plate sensor TPH, then pump P1, P3 and P4 are enabled to run. Plate temperature TPH must be greater than $180^{\circ} \mathrm{F}$ (adjustable) for cooling by the absorption units. A time delay will delay Pump Pl shut down to prevent short cycling. A fan aquastat in the cooling tower will cycle the cooling tower fan to hold sump temperature to $85^{\circ} \mathrm{F}$. (adjustable). SECOND STAGE COOLING

Second stage cooling is accomplished sequencing the existing multi-zone unit and direct expansion units. When second stage cooling is called, the multi-zone unit will be activated. If the discharge air temperature TCD is greater than $60^{\circ} \mathrm{F}$ (adjustable) and second stage cooling is on, the direct expansion unit will then operate. STORAGE TANK CHARGING

Storage tank charging is accomplished only when there is energy avail-: able from the collectors (TPH or TPC - set), and TF in is greater than TSC by $20^{\circ} \mathrm{F}$ (adjustable). Valve $\mathrm{V} 1$ and $V 2$ are positioned $A$ to $A B$ respectively and pumps $P 1$ and $P 2$ are enabled to run. 


\section{PURGE UNIT}

The purge or heat rejection unit is activated by positioning valve V3 $B$ to $A B$ whenever TF out is greater than $200^{\circ} \mathrm{F}$ (adjustable). The fan is under the control of the fan aquastat which cycles the fan on if the discharge temperature is greater than $205^{\circ} \mathrm{F}$.

\section{EQUIPMENT SCHEDULE}

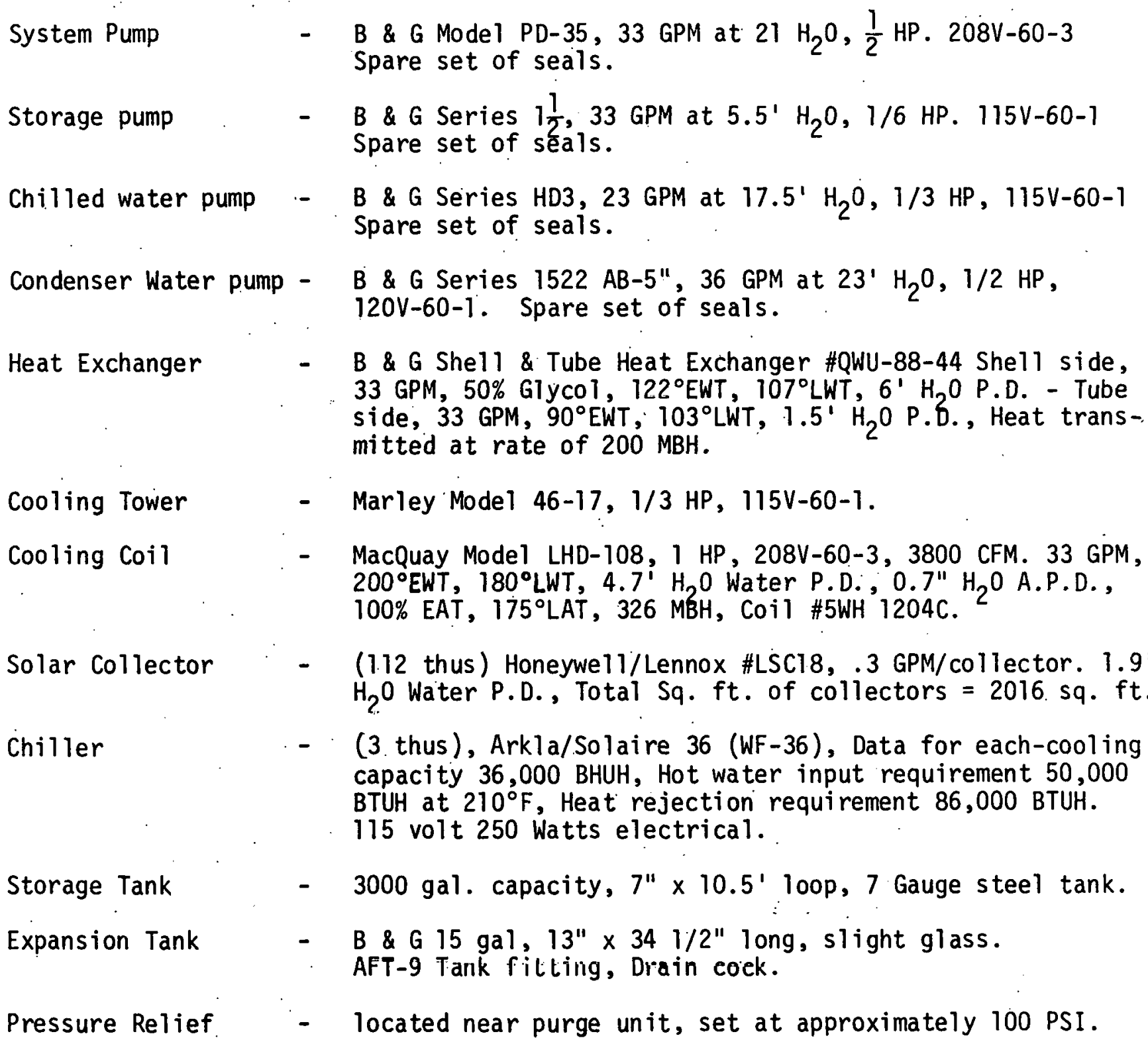


b. Acceptance test results including corrective action taken for nonconformance. Acceptance test was based on the Instrumented Solar Site Status report dated 9-25-78 put out by IBM. (A copy of the report is attached.) The anomalies and actions involving the grantee are summarized in the following table.

$\begin{array}{ll}\text { System } & \text { Anomaly } \\ \text { S/I } & \begin{array}{l}\text { Main system pump } \\ \text { runs continuously } \\ (1 / 78)\end{array}\end{array}$

Action

Control adjustment is Grantee

needed and has been reques led rioui Hüleya well. The problem is due to the way hot deck temperature was set. Damper needs to be readjusted as well as the hot deck temperature so that Valve V7 will cycle to open and close.

\section{S/I}

$$
\begin{aligned}
& \text { Solar energy } \\
& \text { simul taneously } \\
& \text { goes to load } \\
& \text { and storage. } \\
& \text { Does not agree } \\
& \text { with control } \\
& \text { definttion } \\
& (2 / 78)
\end{aligned}
$$

S

$$
\begin{aligned}
& \text { Solar \& aux- } \\
& \text { iliary heat- } \\
& \text { ing (fuel oil) } \\
& \text { have same con- } \\
& \text { trol setting. } \\
& \text { Disagrees with } \\
& \text { control defini- } \\
& \text { tion }(2 / 78)
\end{aligned}
$$

S Solar energy not being taken from storage to meet heating load $(2 / 78)$

S

$$
\begin{aligned}
& \text { Single plate } \\
& \text { temperature } \\
& \text { control sensor } \\
& \text { may cause over } \\
& \text { heating. }
\end{aligned}
$$

Control definition has been changed and drawing has been corrected. Storage is not used for cooling.

\section{Damper cam should be Grantee} readjusted to start solar heating prior to auxiliary heating. We have requested Honeywell controls to make due adjustment.

See above

I BM/Grantee

$$
\begin{array}{ll}
\text { Grantee } & \begin{array}{l}
\text { It was } \\
\text { okayed to } \\
\text { delete this. }
\end{array}
\end{array}
$$




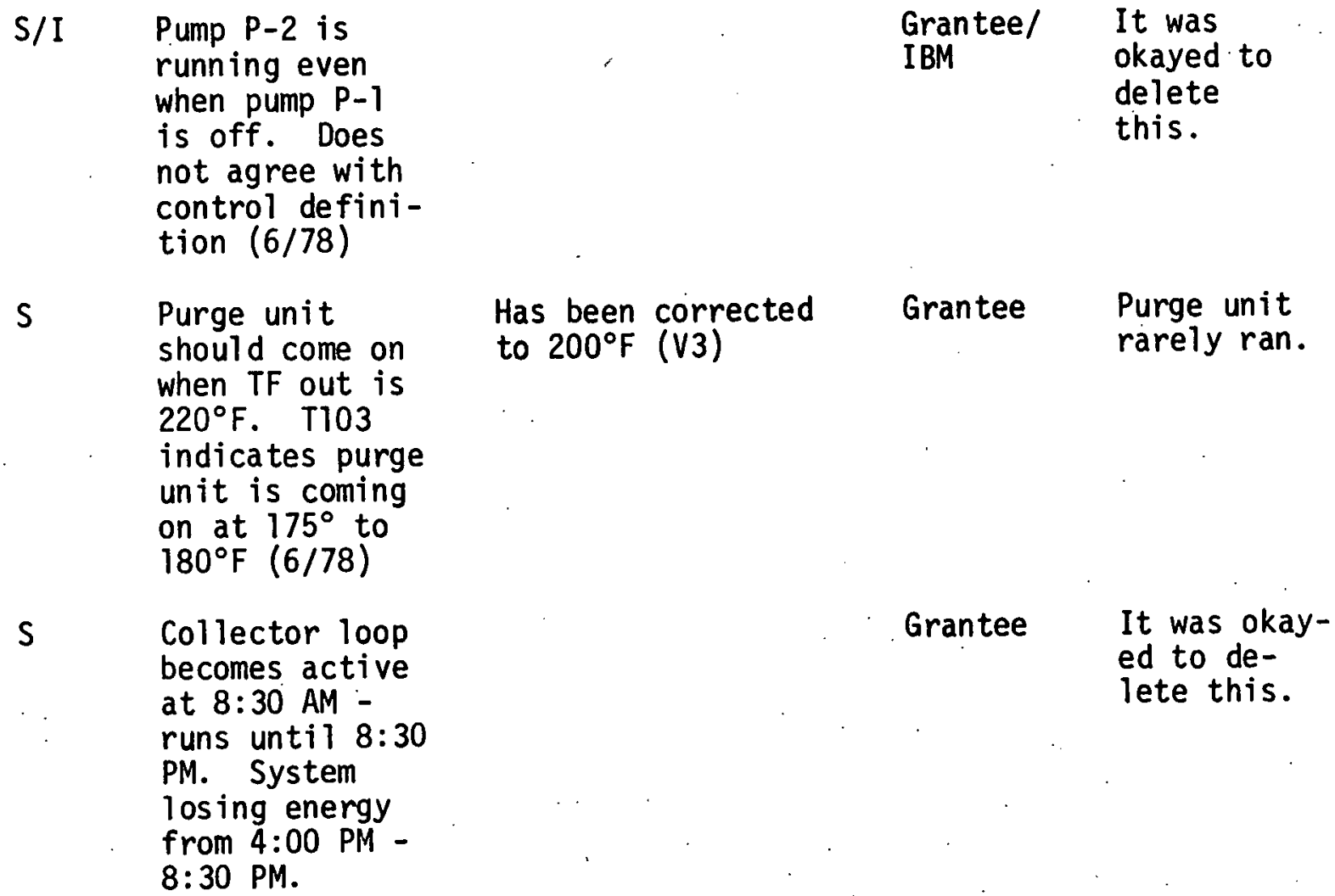

3. Complete set of as-built drawings with wire and piping schematics. 


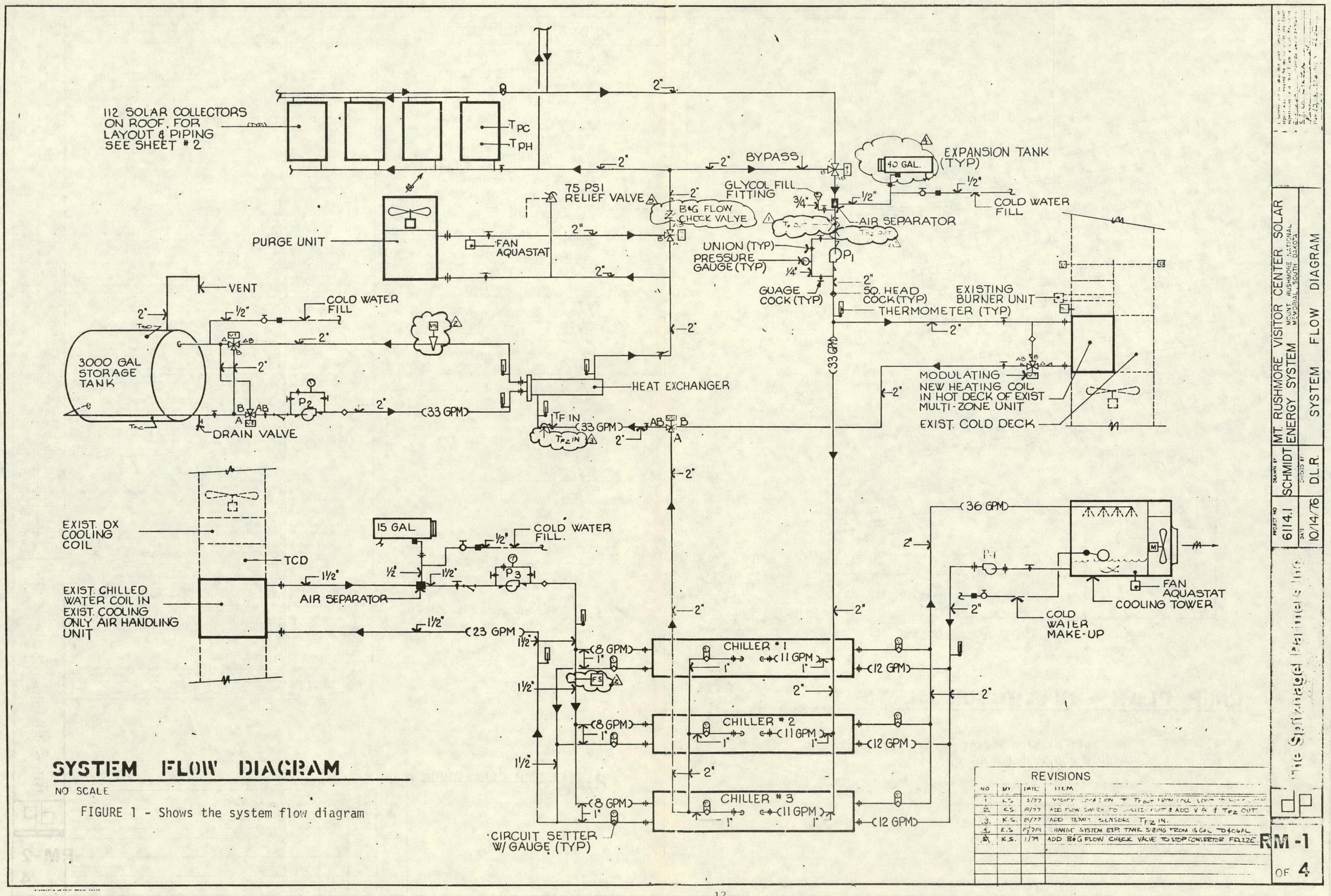




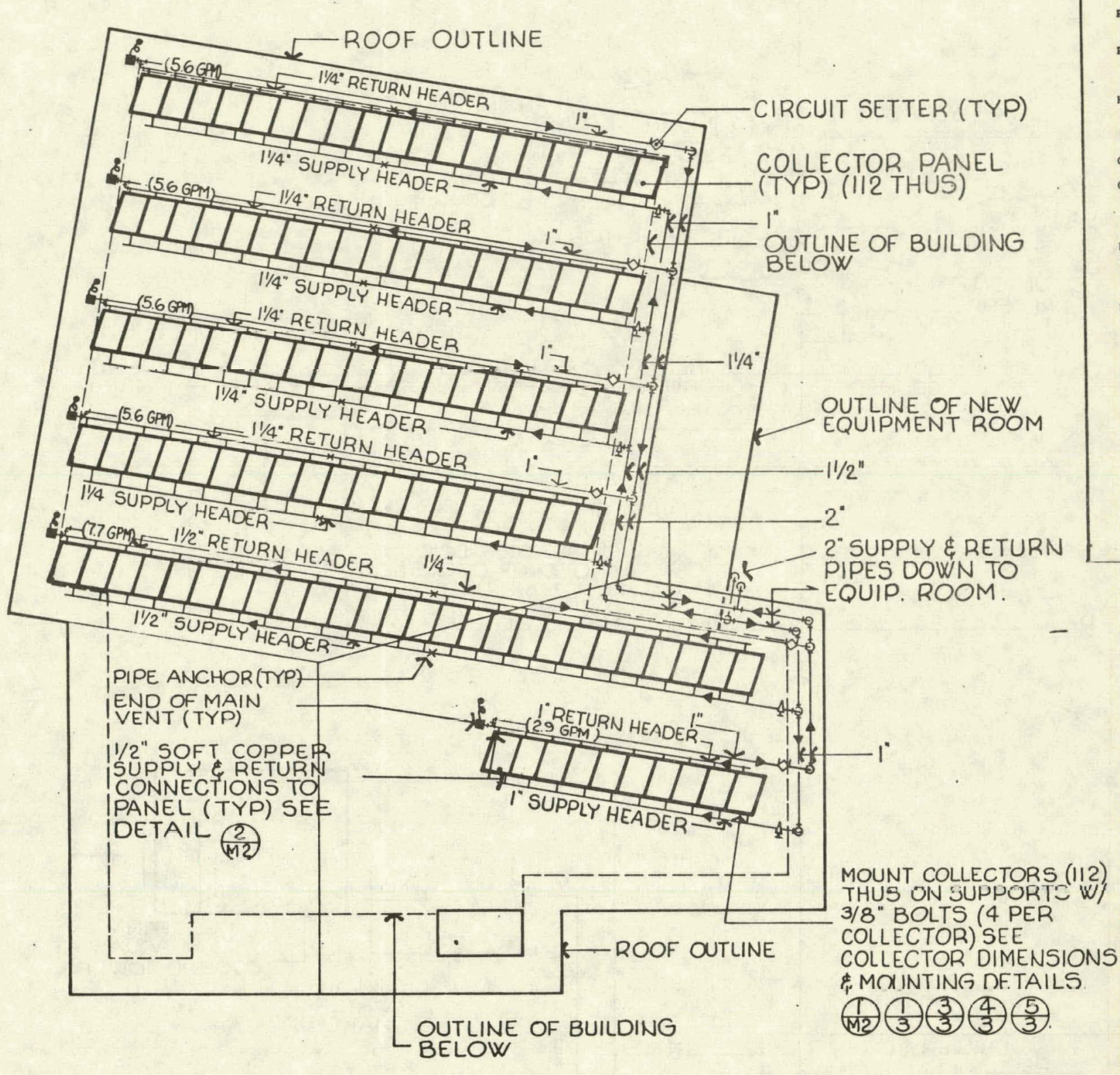

\section{PO()OIF PLAN - (:OLLLE(:TOIR LAYOUUT}

SCALE: $1 / 8^{\prime \prime}=1 '-0^{\prime \prime}$

- FIGURE 2 - Shows roof plan-collector layout with equipment schedule and sequence, of operation $69030^{\circ}$
EQUIPMENT SCHEDULE

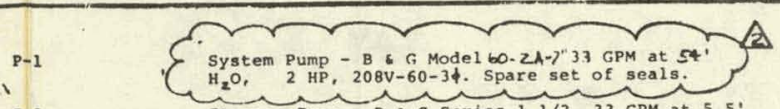

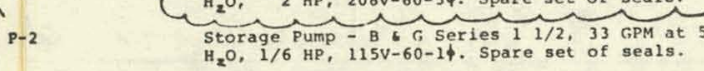

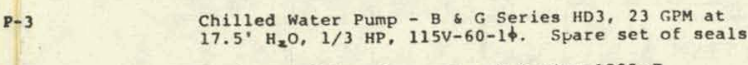

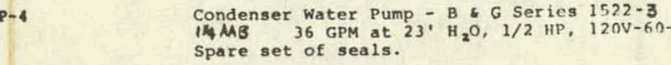

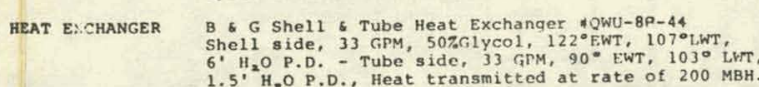

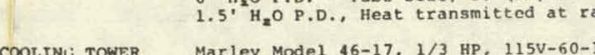

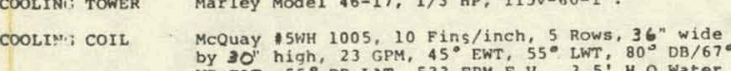

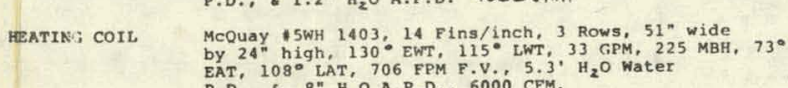

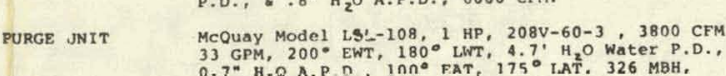

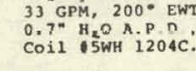

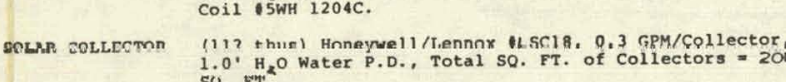

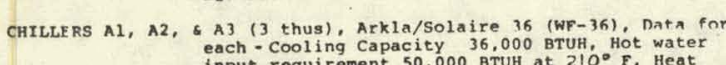

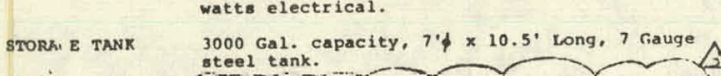
expen: ion truns (

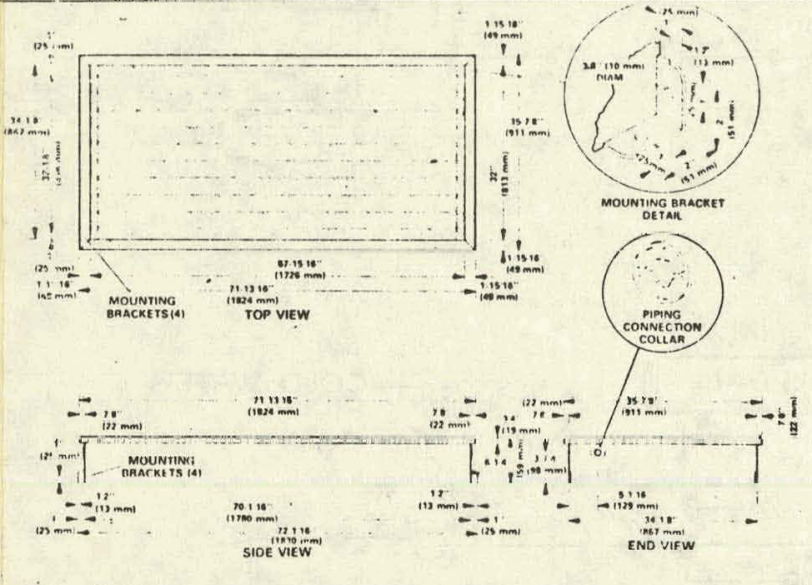

I $\frac{\text { COLLECTOR DIMENSIONS }}{\text { NO SCALE }}$

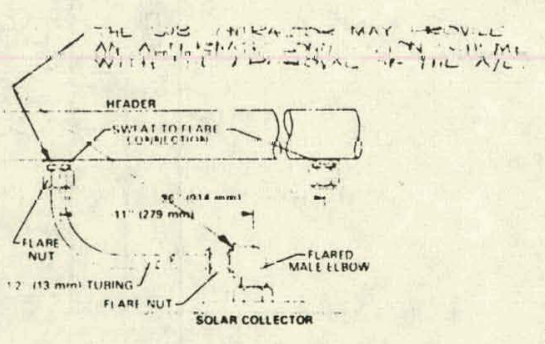

2. $\frac{\text { COLLECTOR CONNECTIONS }}{\text { NO SCALE }}$

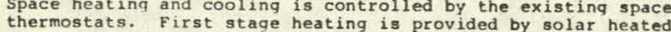
$\begin{array}{ll} & \\ & \end{array}$

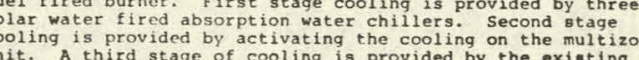

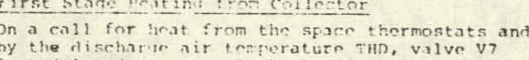

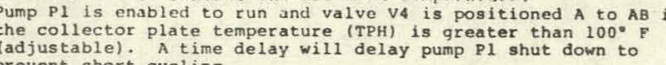
irat stage Heating from storage

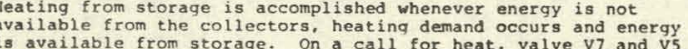
in the heating positions. valve $v_{4}$ is $B$ to $A B$. Pump $\mathrm{P} 2$

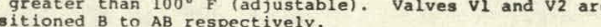
cond and Third Stage Heating

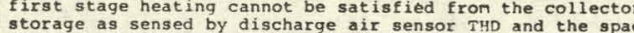
st stage cooling from collectors 作 through AJ the collectorss

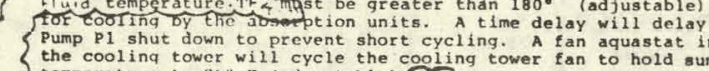

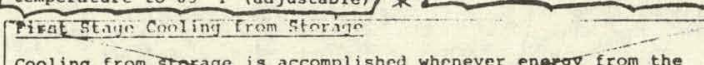

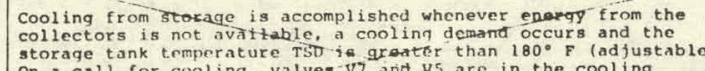

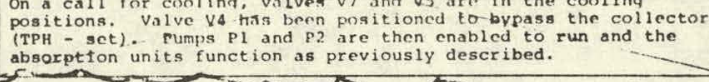

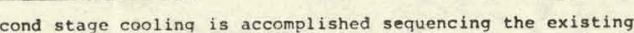

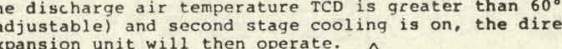
Eorage Tank charging $\underbrace{\text { No cooling }}_{0.00}$

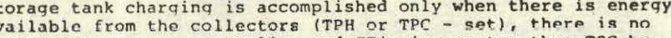

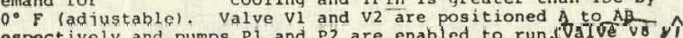
the vite

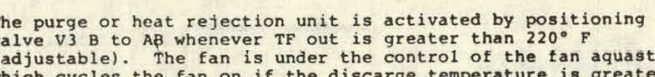
than $21^{\circ} \cdot 0^{2}$

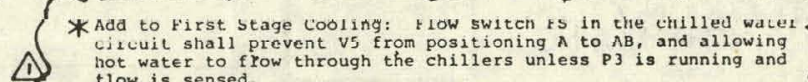

storagec Tank charging men cool ing,

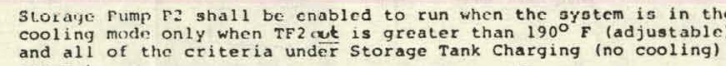

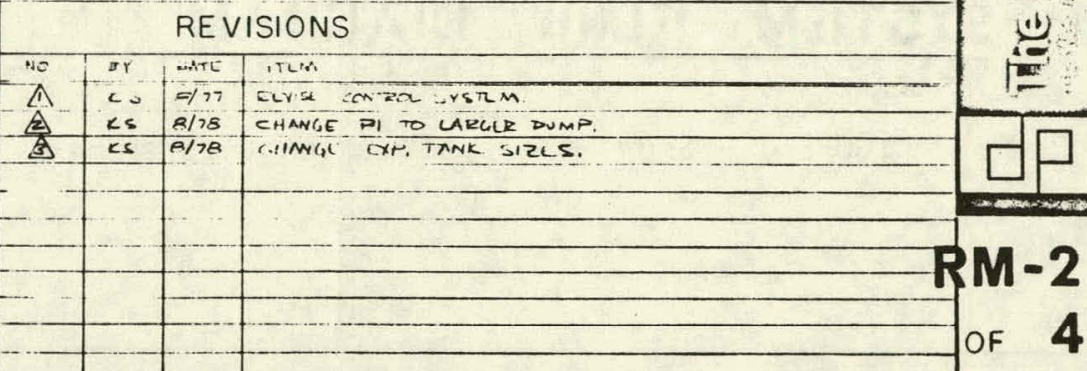




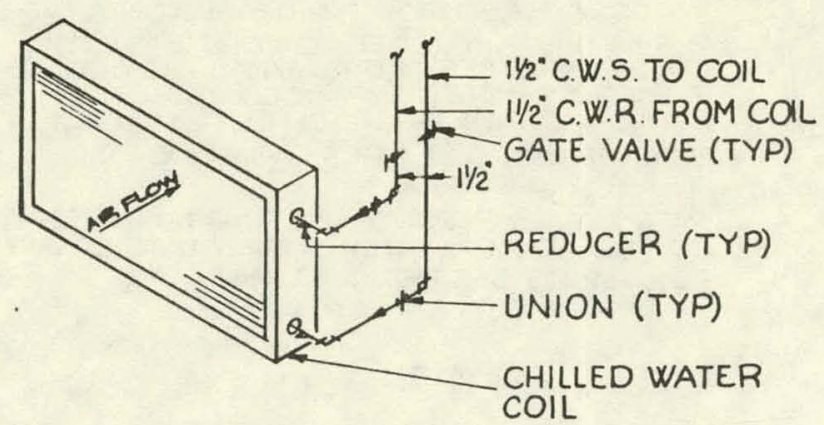

I COOLNG COIL PIPING DETAIL

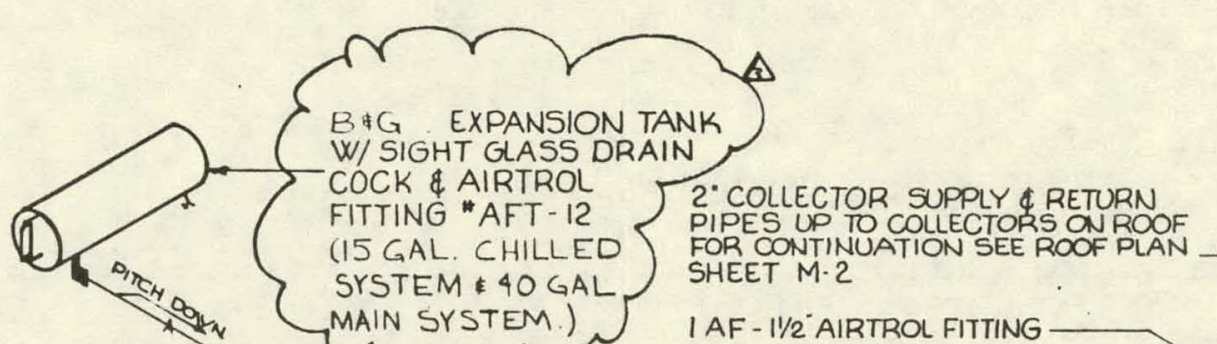
Th $x$ AIR AIR UINE FROM

CHECK VALVE
GLOBE VALVE
VACUUM BREAK

6 EXPANSION TANK 1/2"AIR LINE TO EXP.
TANK SEE DET. 4 R-2 ROLAIRTROL
CHILED WATR P PMP -
GATE VALVE. (TYPP)
SYSTEM PUMP -

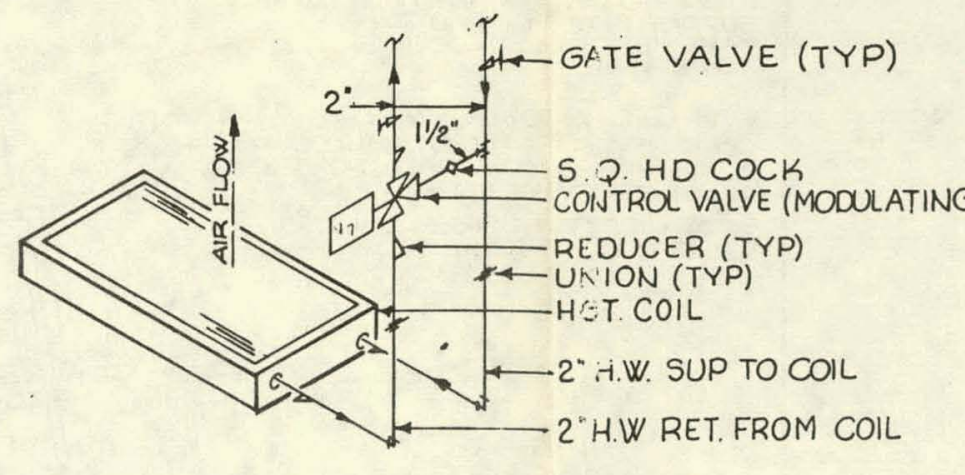

?. HEATING COIL PIPING DETAIL

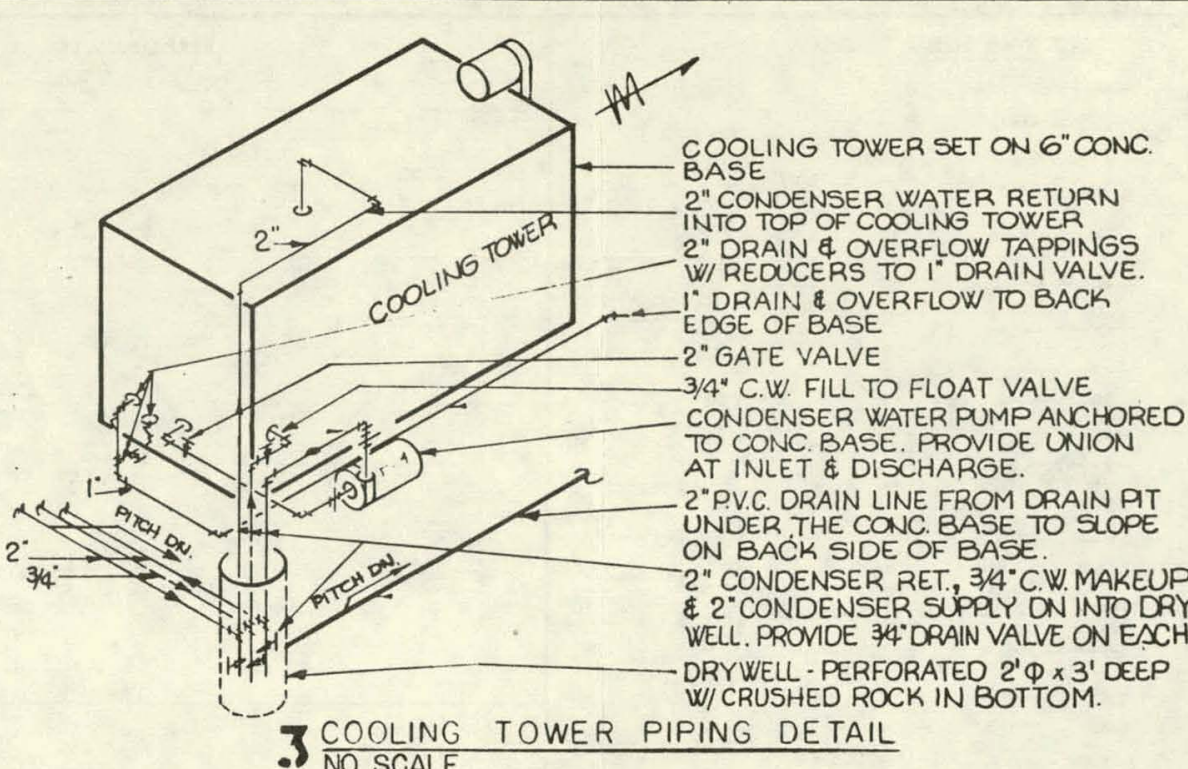

2" HWW SUP \& RET TO
HGT.COLL IN EXIST.
MUUT

MULTIZONE UNIT

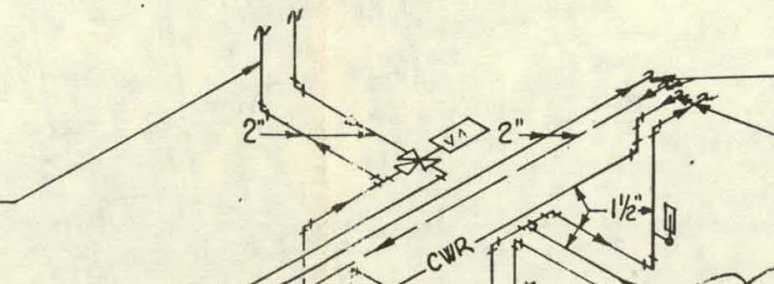

TO COOLING COLIIN
EXIST SINGL ZONE EXIST SING
UNIT. IAF- II/2 AIRTRO FITTING
I/2"AIR LINE TO EXP.
TANK SEE DET.

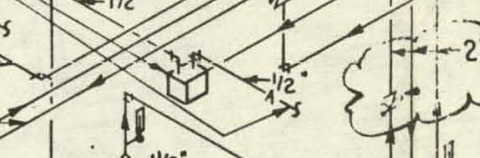

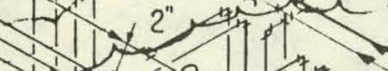

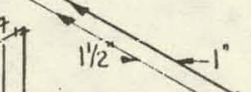
$-1 \rightarrow=1$

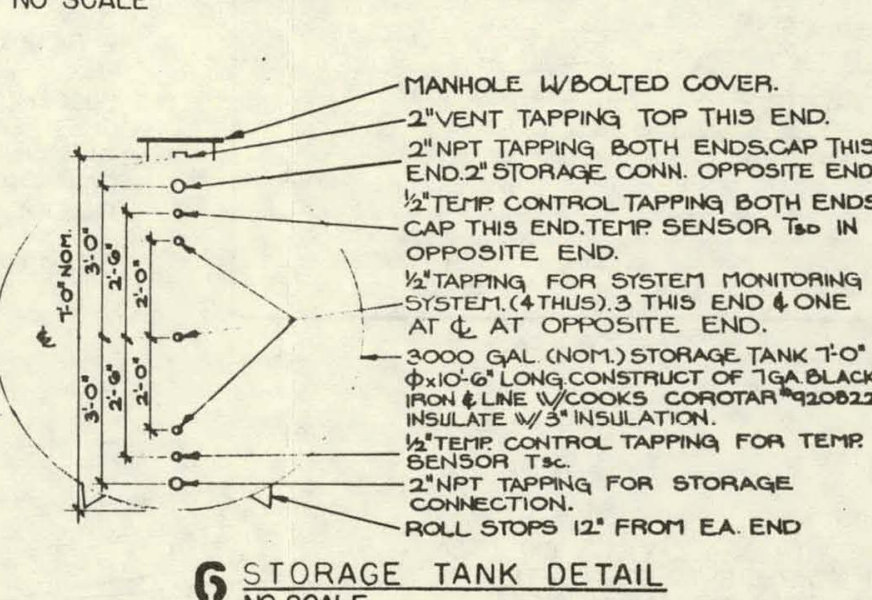
65 STORAGE TANK DETAIL

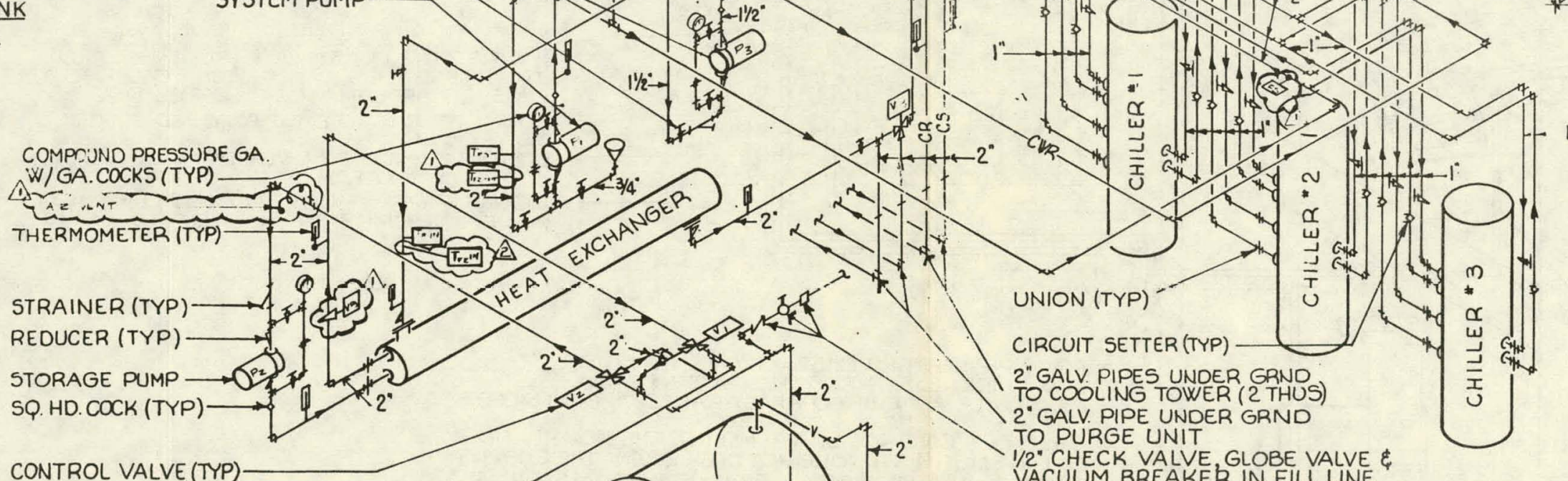

CONTROL VALVE(TYP)

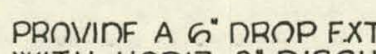
WRITH HORIZ. 2 . DISCH INSIDE TANK. OFFSET

FIGURE 3 - Shows piping system

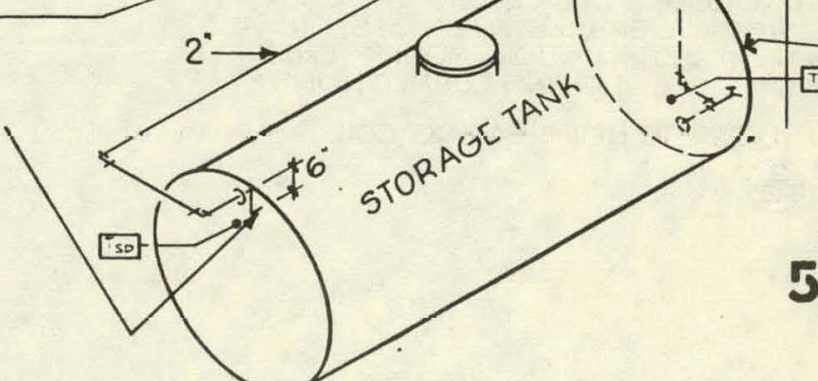

5 SOLAR ENERGY SYSTEM PIPING DETAIL 75 PSI RELIE
VALVE

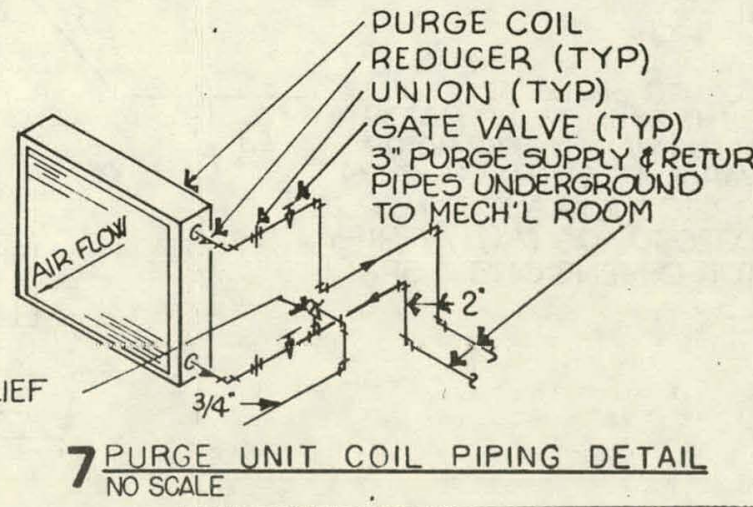
REVISIONS

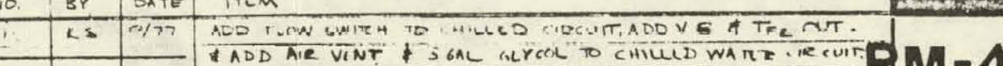

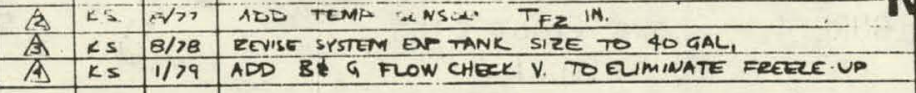




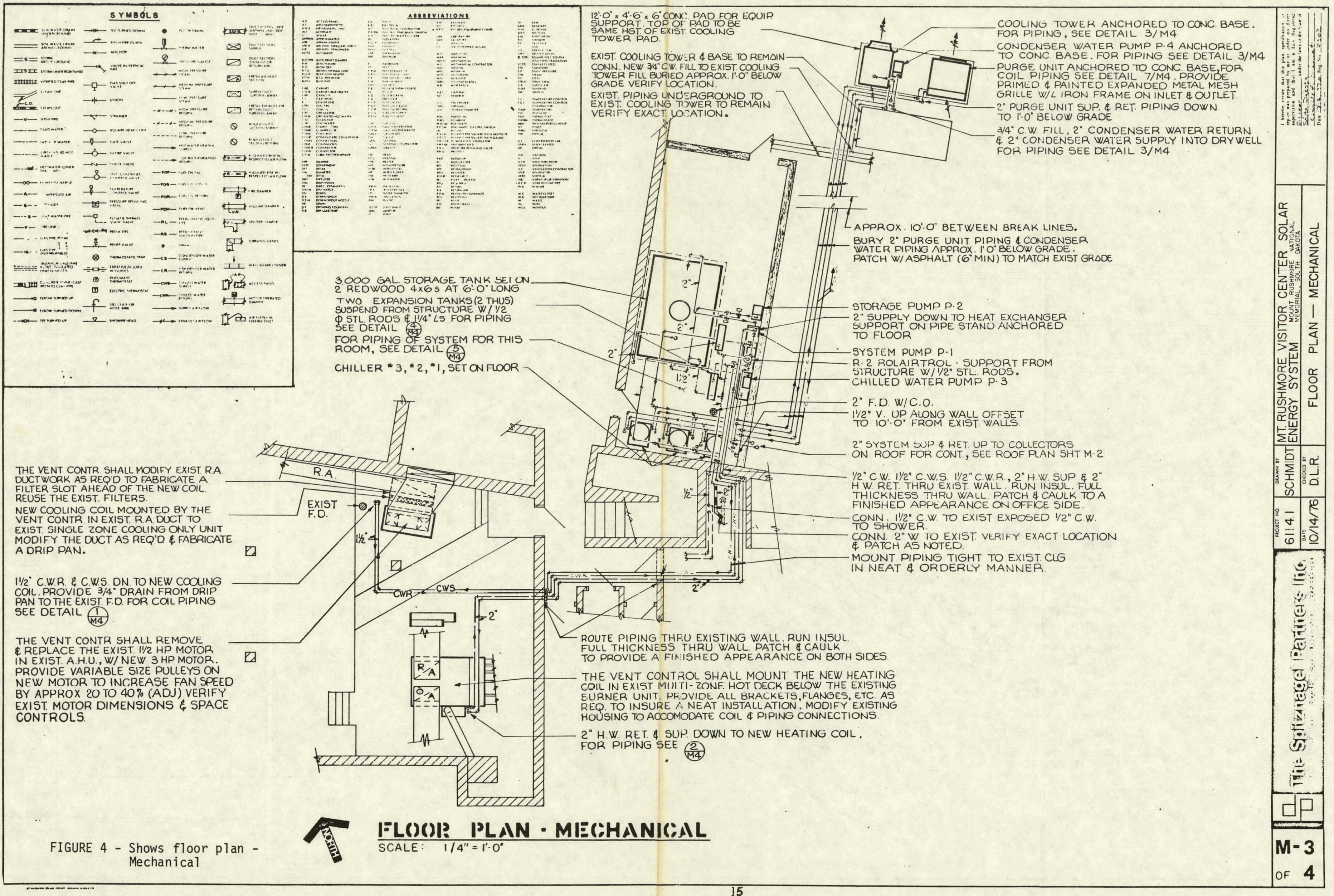



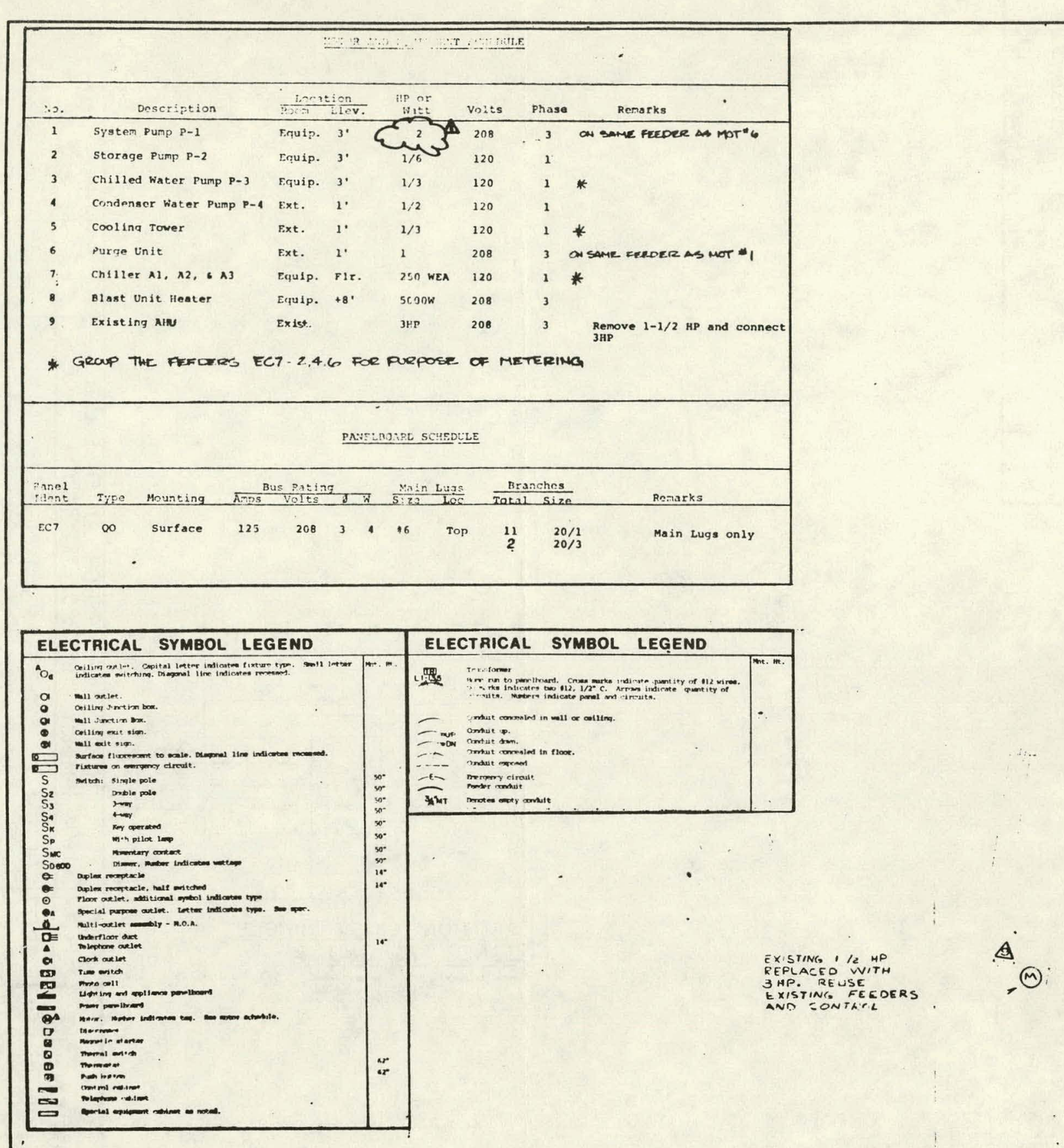

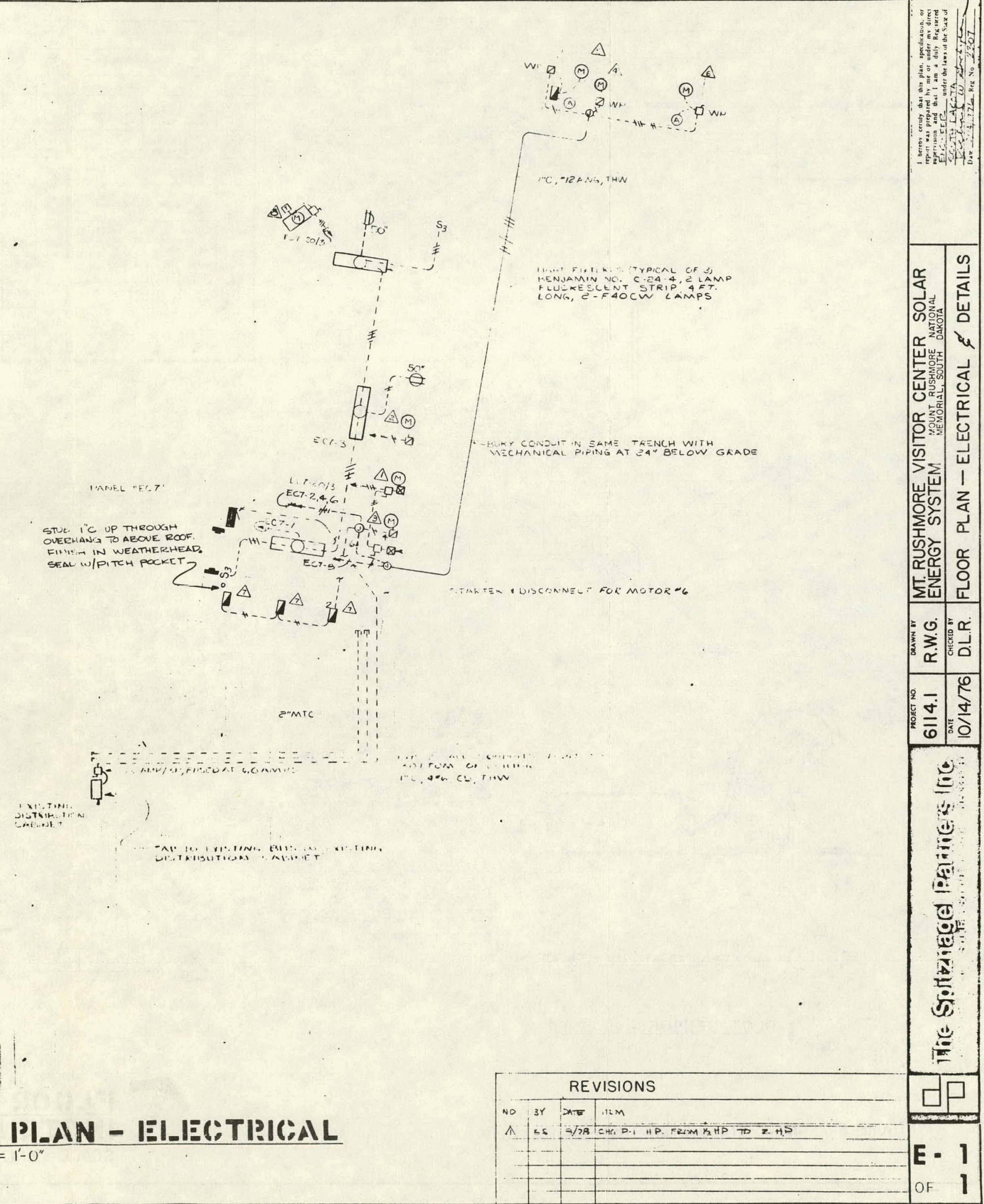




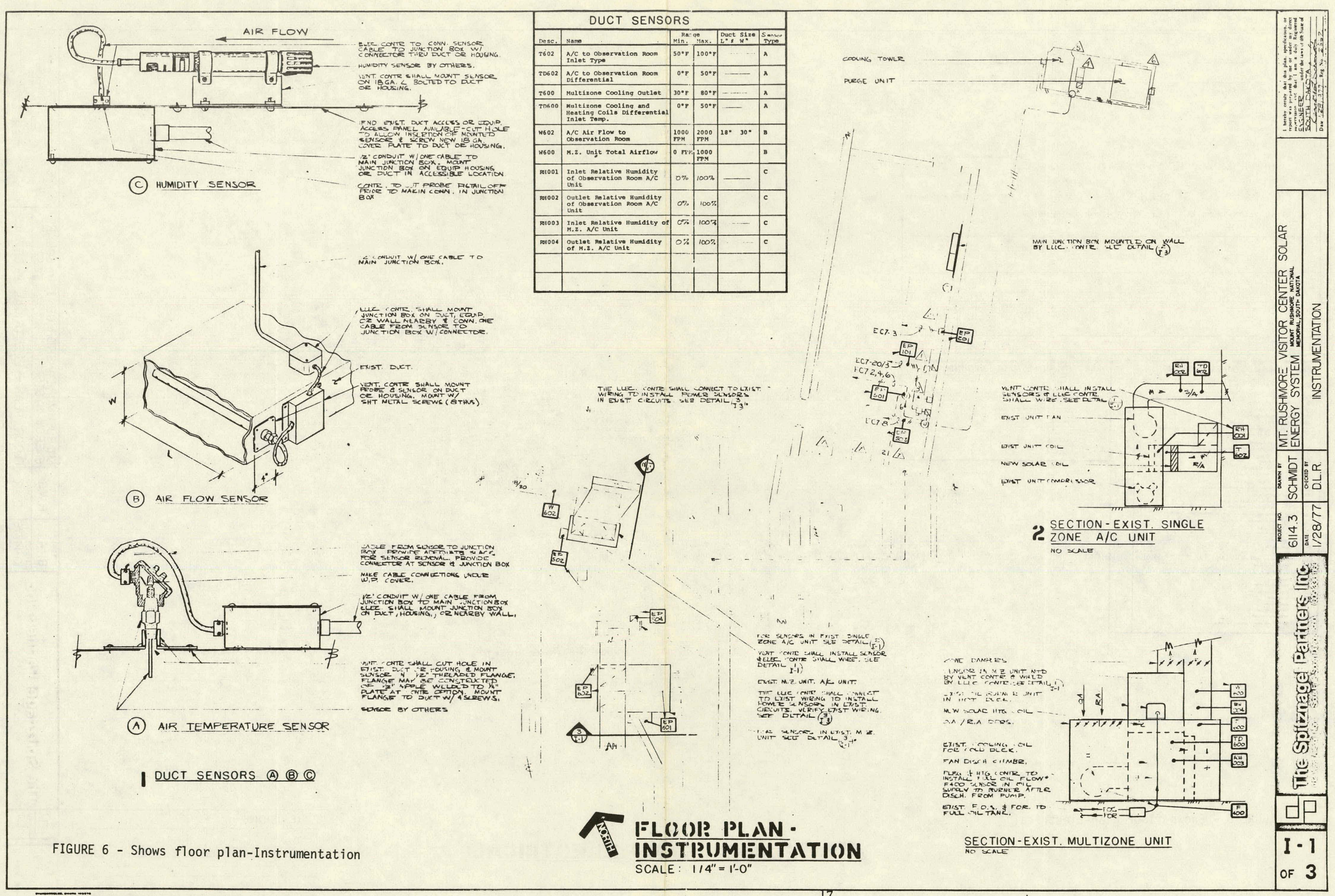




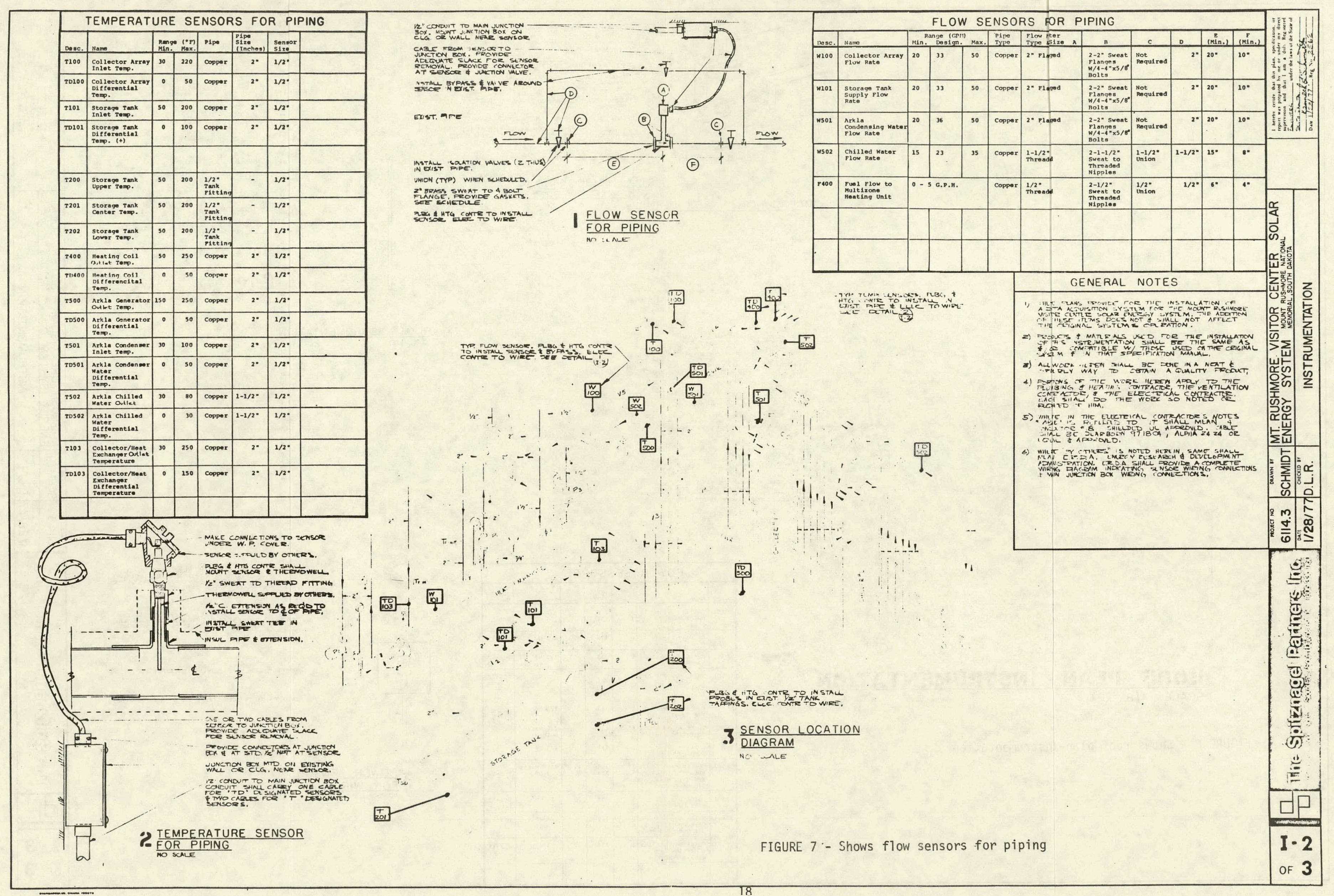




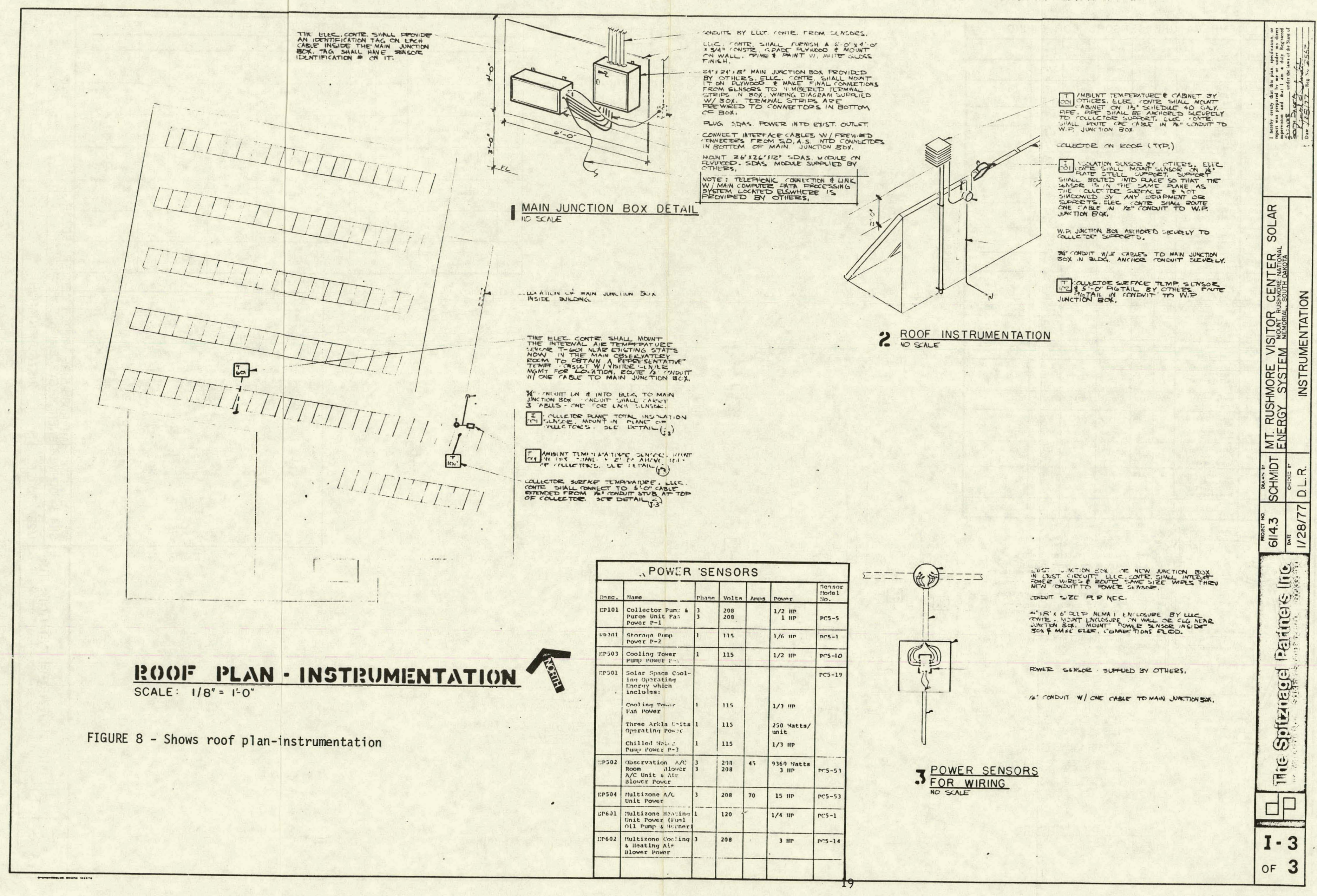


4. Operation and Maintenance Manual

Due to the fact that the $0 \&$ MM is too bulky to make a part of this report for many reproductions, three complete copies of this manual are available at the following locations. One is located at the site of Mount Rushmore Visitor's Center; one as contractor's file at MSFC: and one in the office of Dr. C. W. Chiang, Mechanical Engineering Department, South Dakota School of Mines and Technology, Rapid City, SD 57701. 5. Pictures of final installation. 


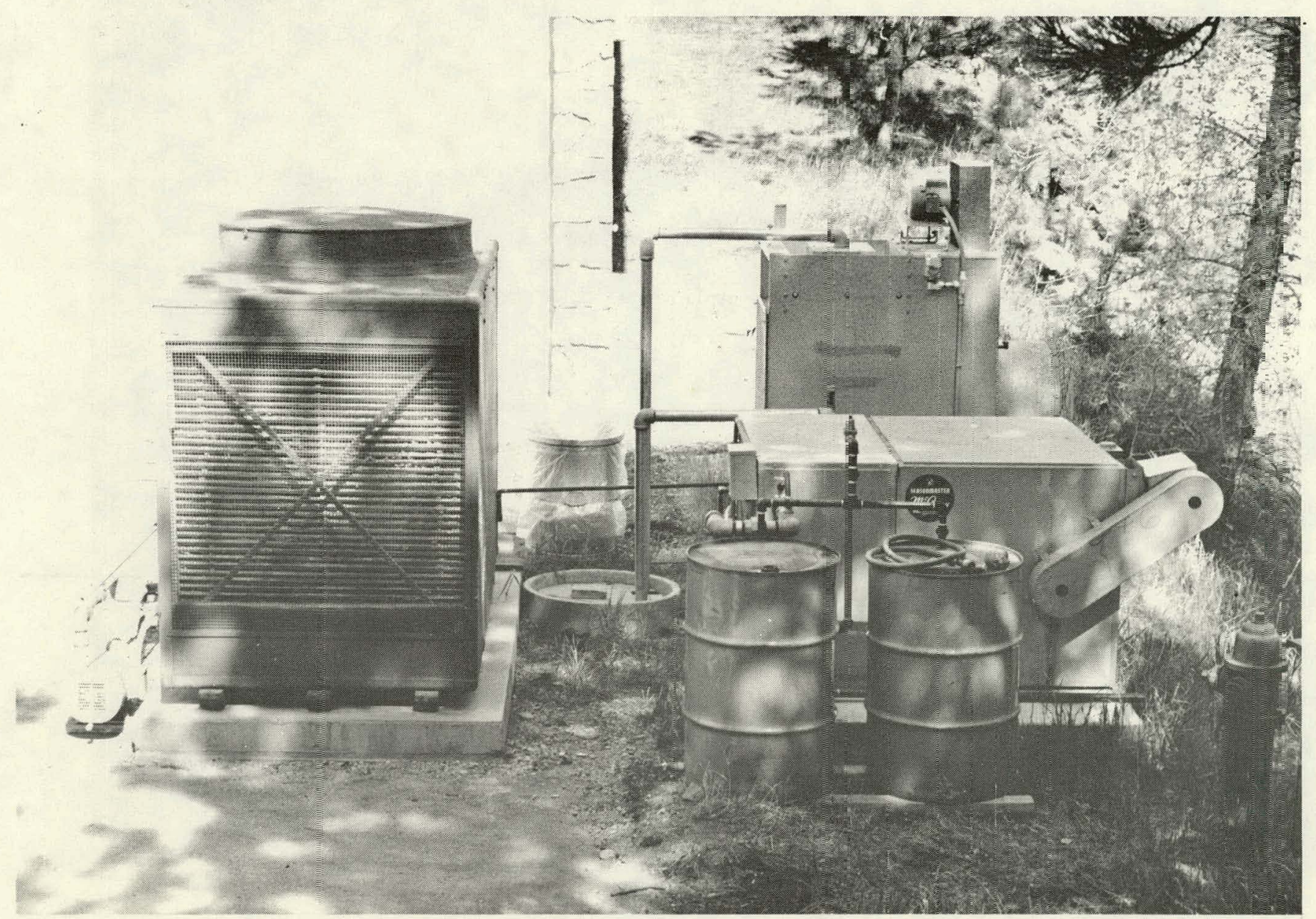

PURGE UNIT AND EXISTING COOLING TOWER 


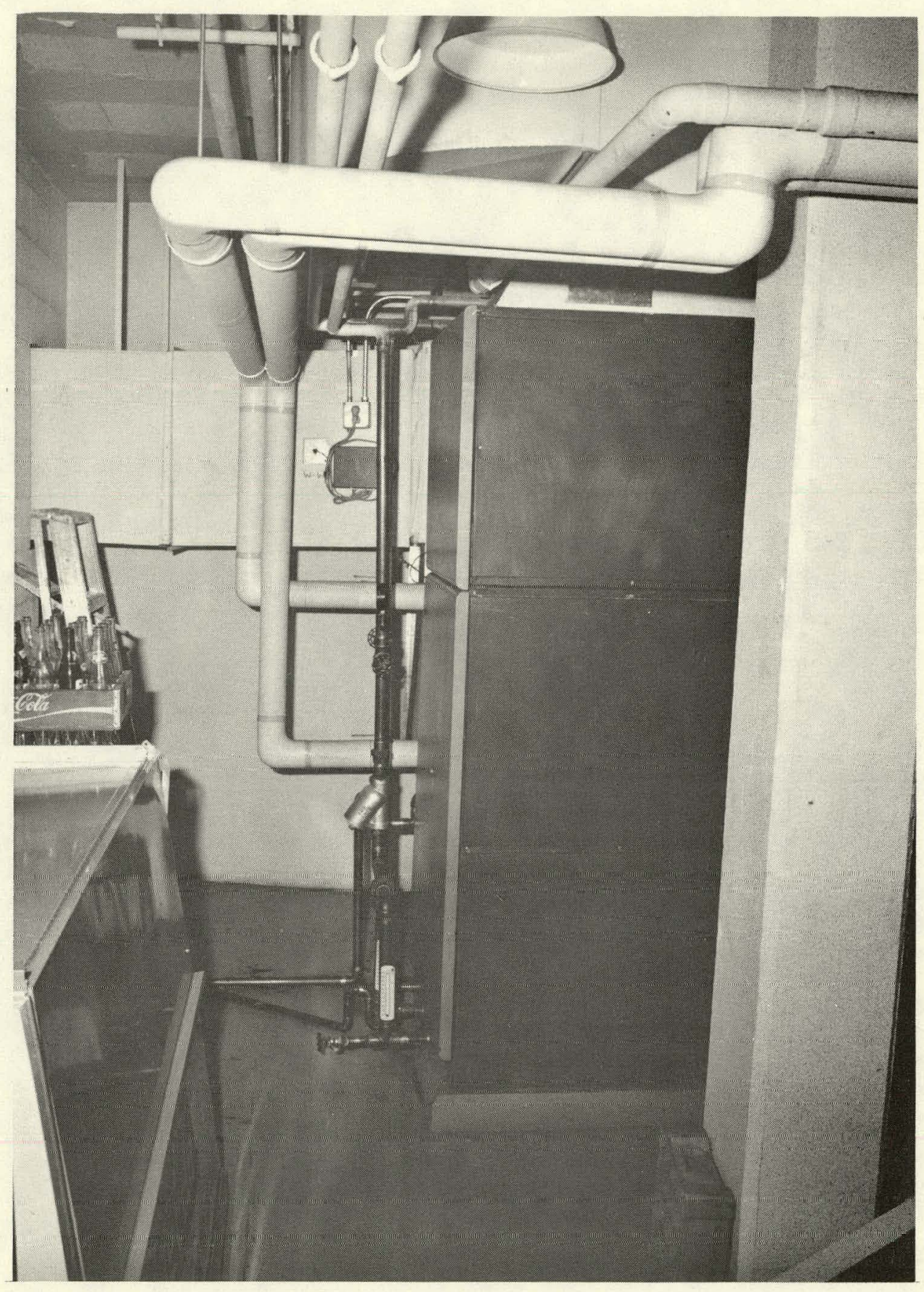

COOLING COIL AND PIPING TO EXISTING AIR HANDLING UNIT 


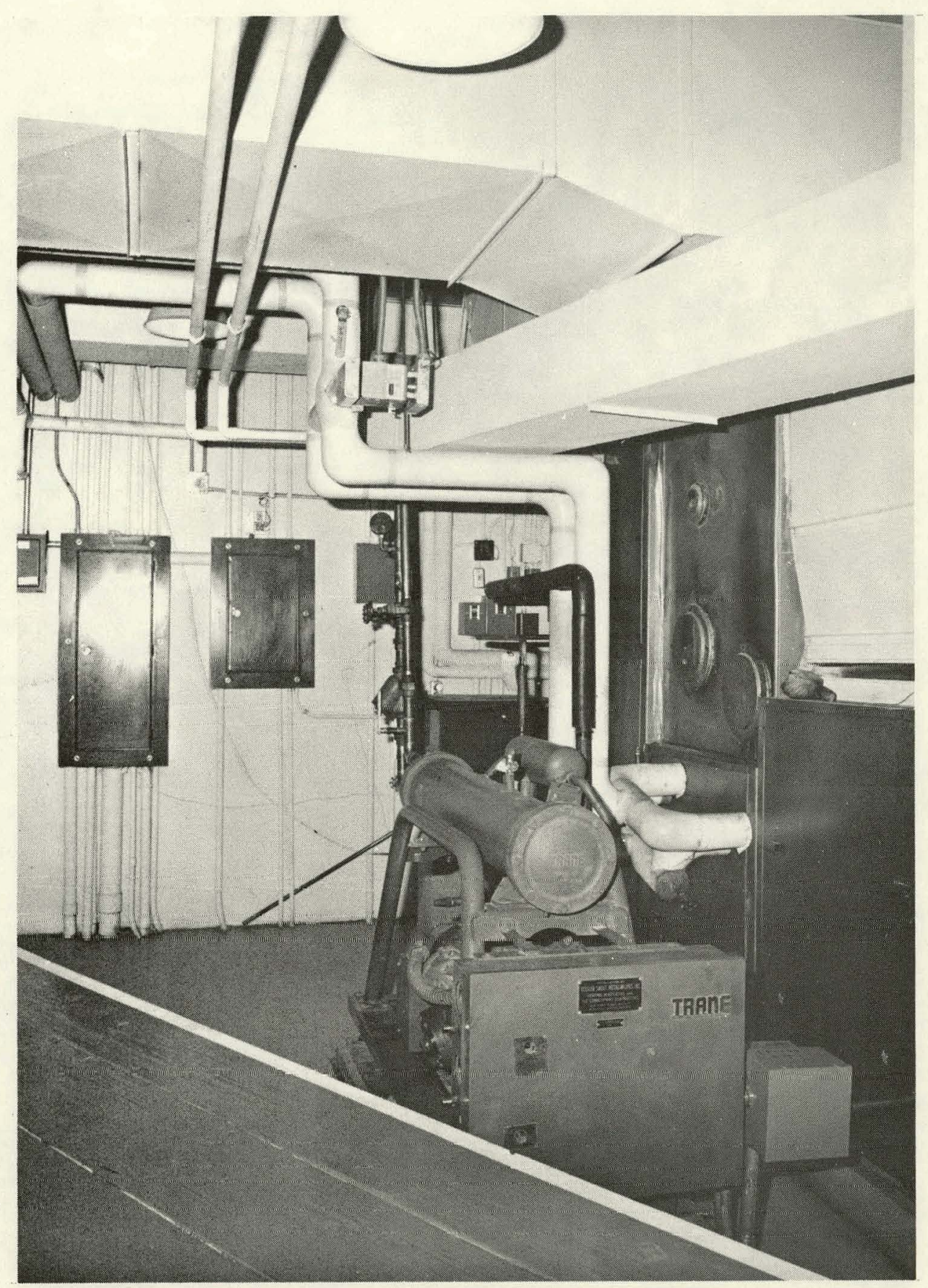

HEATING COIL WITH PIPING IN VALVE LEADING

TO EXISTING FURNACE 


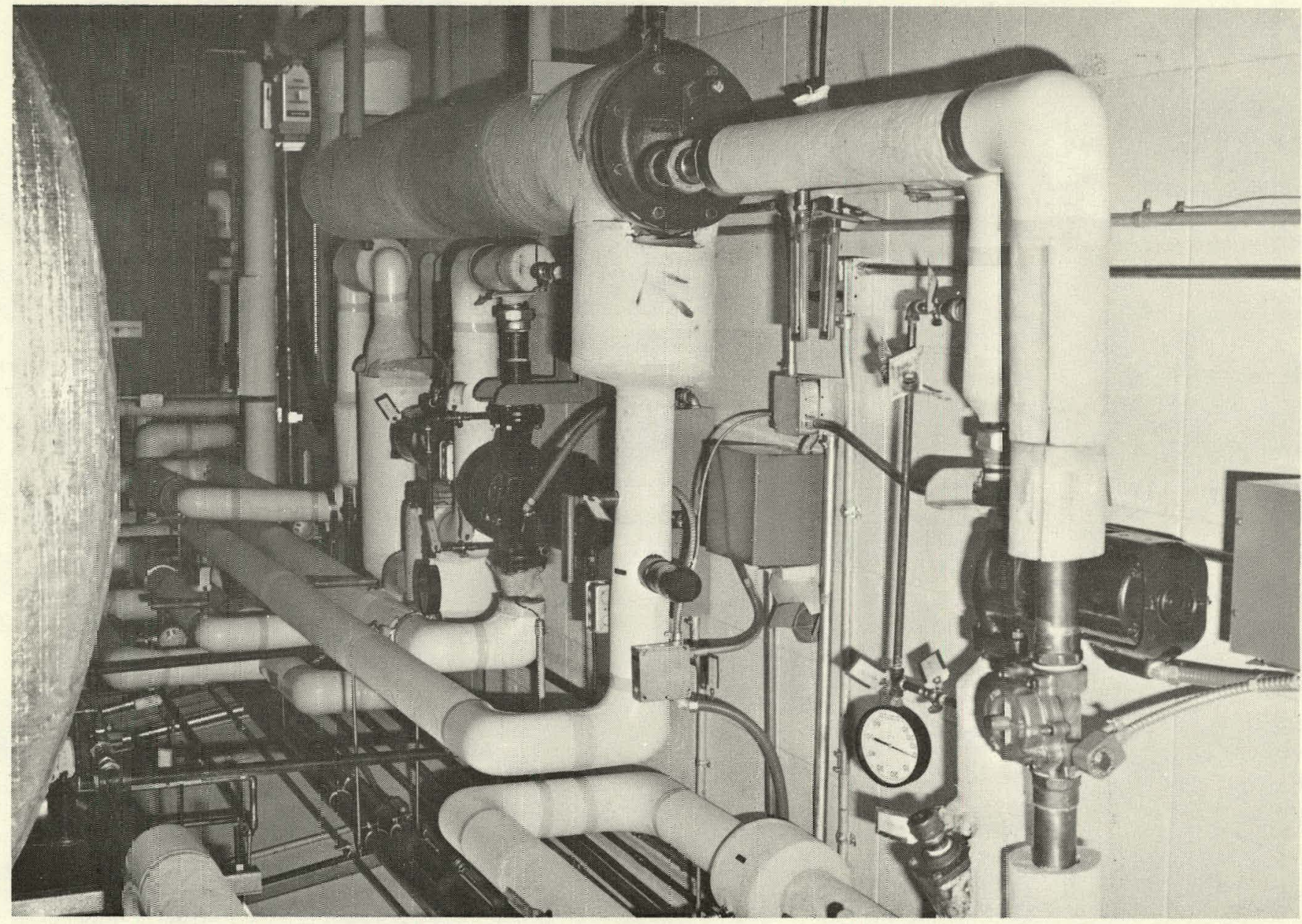

HEAT EXCHANGERS, PUMPS AND PIPING AT THE RIGHT PART OF STORAGE TANK AT THE LEFT 


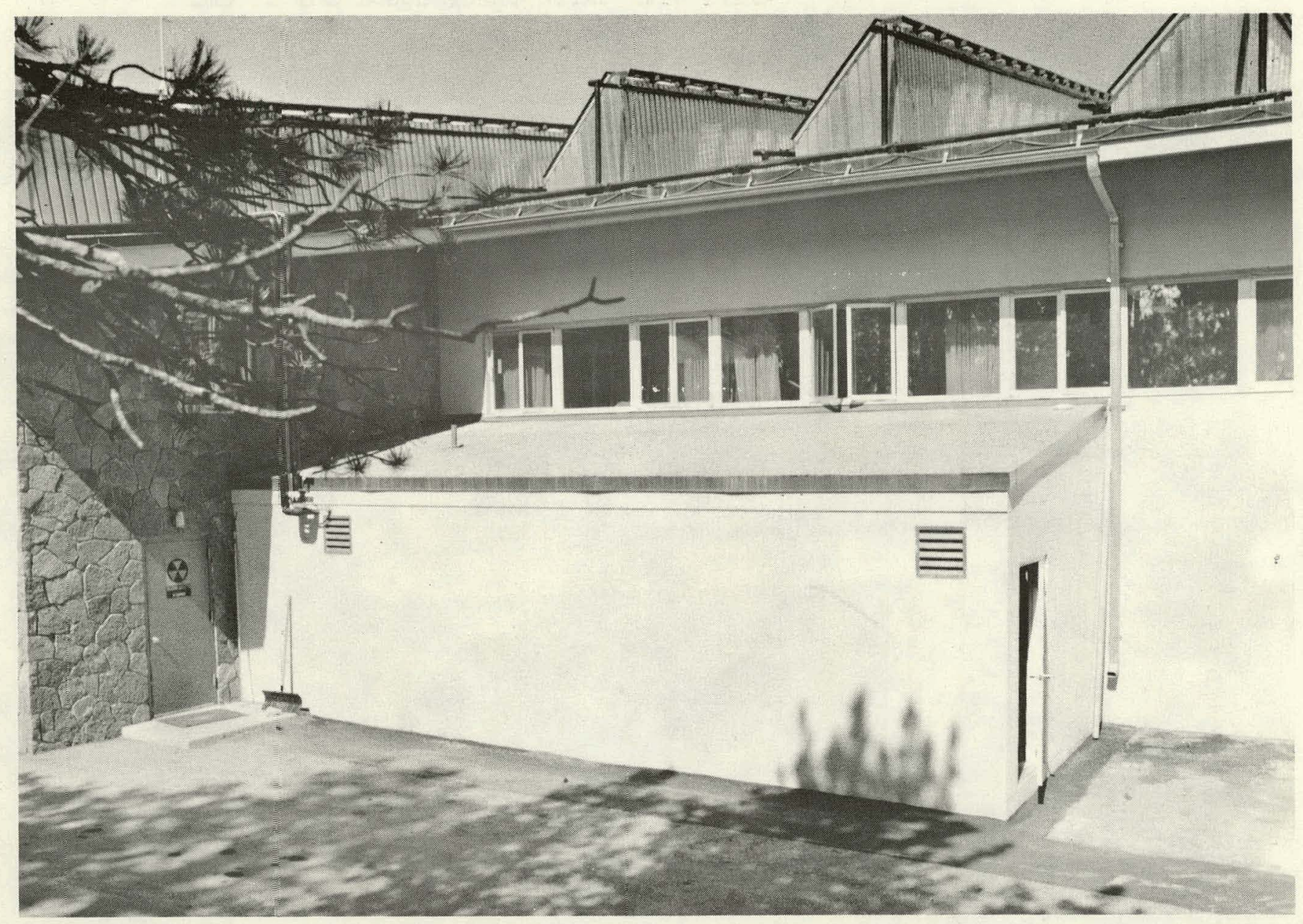

ROOM ADDITION HOUSING

STORAGE TANK AND MECHANICAL SYSTEMS 


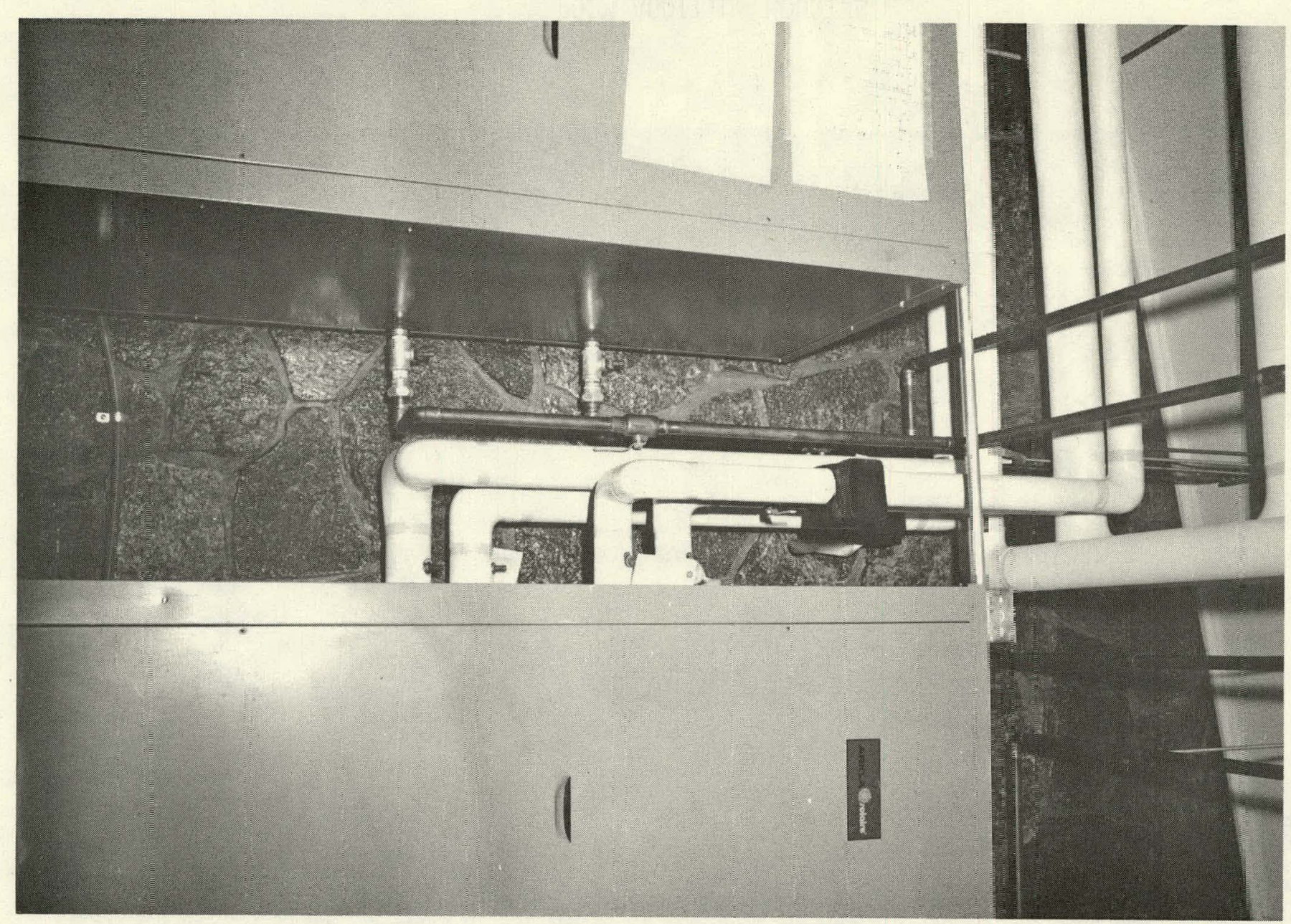

TWO OF THE THREE ARKLA UNITS WITH PIPING 


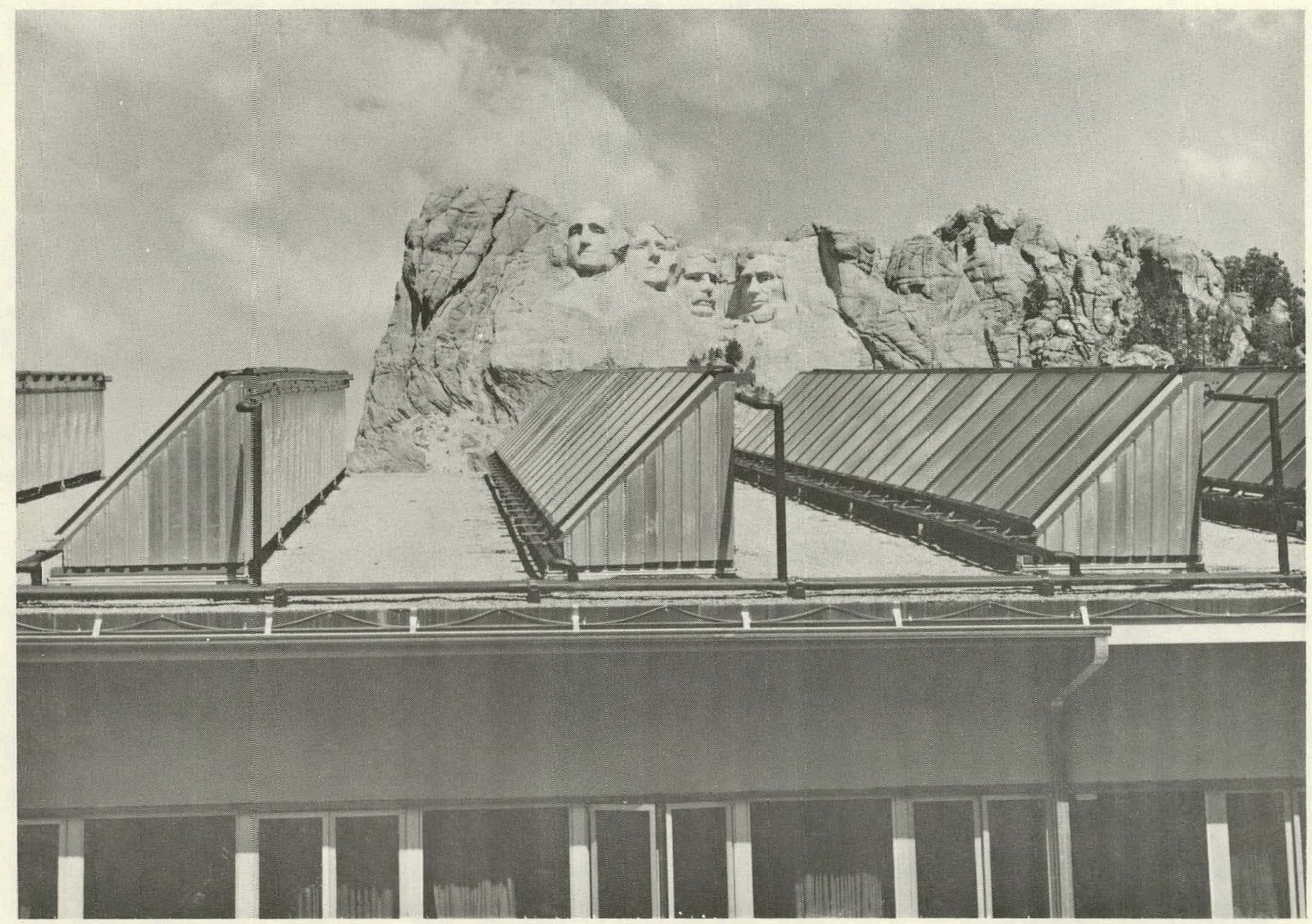

COLLECTORS WITH PIPING ON THE ROOF 


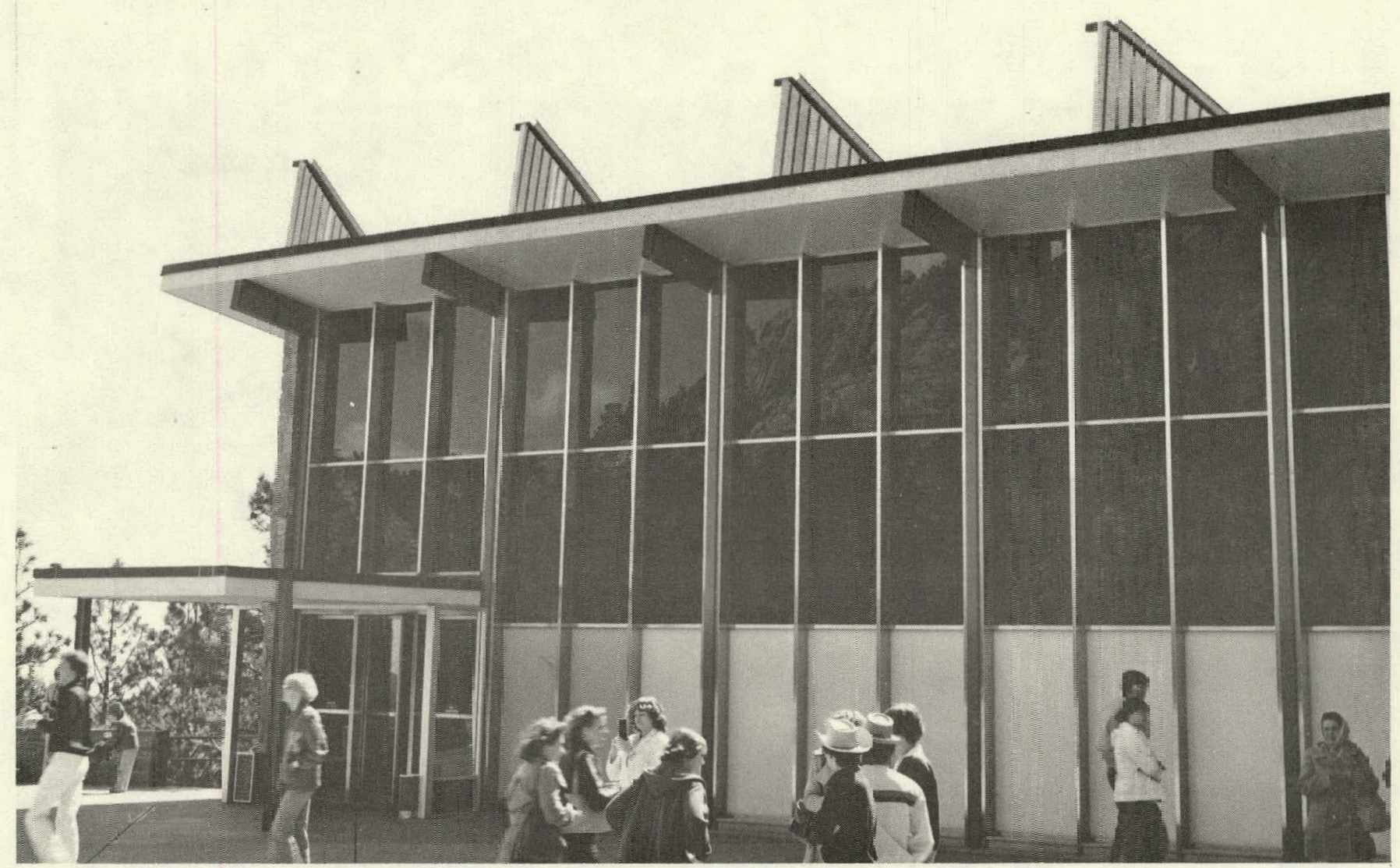

COLLECTORS ON THE ROOF

SIDE VIEW 


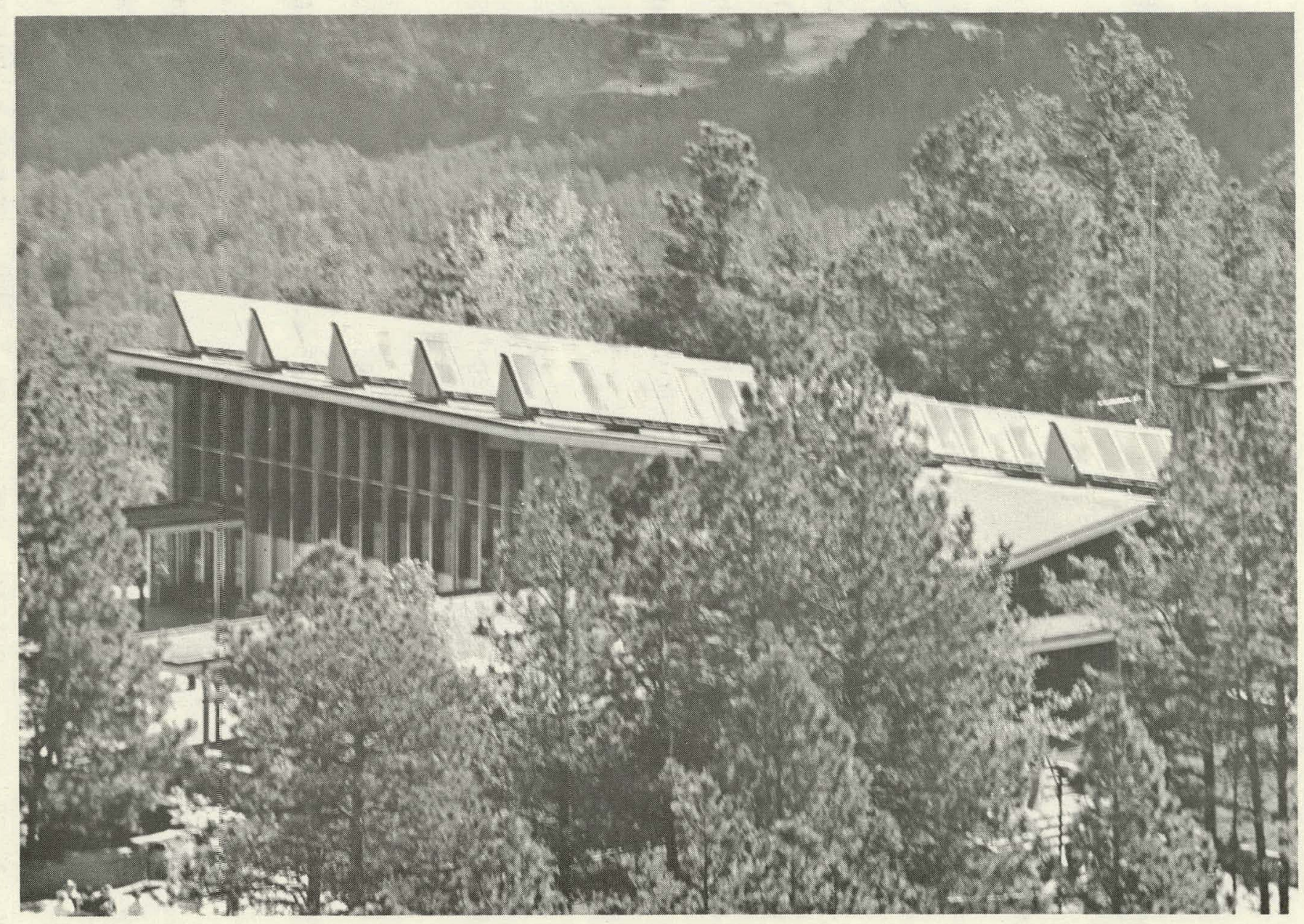

View of Complete Collector Arrays on the roof of Mount Rushmore Memorial Visitor Center 


\section{Predicted System Performance Data}

Heating load calculations indicate a maximum heating load of 400,000 $\mathrm{Btu} / \mathrm{hr}$ for severe winter, as shown by Table B. 3-1. The total fuel consumed in FY 1975 was 8721 gallons of No. 2 oil. Assuming a heating value of $140,000 \mathrm{Btu} / \mathrm{gal}$ and a furnace efficiency of 50 percent due to the age of the furnace and an altitude of about one mile, the total conventional heat supplied was about $6.1 \times 10^{8} \mathrm{Btu}$.

Load calculations of the observatory room indicate a cooling load of 15-ton refrigeration needed as shown by Table B, 3-2. Solar energy system calculations were based on climatological data of Rapid City supplied by the National Oceanic and Atmospheric Administration (NOAA). The climatological conditions at Mount Rushmore ( 25 miles southwest and 2000 feet higher than Rapid (ity) are more favorable due to the altitude and lack of pollution in the air, making these calculations conservative.

The calculations are based on $2000 \mathrm{ft}^{2}$ of Honeywell LSC-18-1 doubleglazed collectors tilting at a slope of 45.7 deg and facing 18.8 deg west of south. These angles are the result of mounting the collectors at 45 deg with respect to the roof, which has a slope of 9.3 deg facing 28 deg south of east. The collectors have a transmissivity absorptivity product of 0.84 and a heat loss coefficient of $0.68 \mathrm{Btu} / \mathrm{hr}-\mathrm{ft}^{2}-{ }^{\circ} \mathrm{F}$. The fluid flow rate is taken to be $40 \mathrm{gpm}$. The heat demand of the building, based on the actual heating data, was taken to be $2900\left(70-\mathrm{T}_{\mathrm{amb}}\right) \mathrm{Btu} / \mathrm{hr}$. The heat available from the solar system was taken to be $500\left(T_{s t}-90\right)_{x}+500\left(T_{s t}{ }^{-T_{a m b}}\right) . \quad\left(T_{s t}=\right.$ storage temperature, $T_{a m b}=$ outside temperature.) This assumes a heating coil design which allows $200,000 \mathrm{Btu} / \mathrm{hr}$ heating with $130^{\circ} \mathrm{F}$ water and no heating at $90^{\circ} \mathrm{F}$ and pre-heat coil for 10 percent ventilation. The heat capacity of storage was taken to be $32,000 \mathrm{Btu} /{ }^{\circ} \mathrm{F}$. The solar insolation was calculat- 
Table B.3-1. Heating Load Calculation

\begin{tabular}{|c|c|c|c|c|c|c|c|c|c|}
\hline Roon Name: & $\begin{array}{c}\text { Dimension } \\
\mathrm{ft} \times \mathrm{ft}\end{array}$ & $\begin{array}{c}\text { Infiltra- } \\
\text { tion } \\
\mathrm{ft} \\
\end{array}$ & $\begin{array}{c}\text { Glass } \\
\mathrm{nt}^{2} \\
\end{array}$ & $\begin{array}{l}\text { Wall } \\
\mathrm{nt}^{2} \\
\end{array}$ & $\begin{array}{c}\text { Rnof } \\
\mathrm{ft}^{2} \\
\end{array}$ & $\begin{array}{c}\text { Finor. } \\
\mathrm{ft}^{2}\end{array}$ & I3tu/hr & Factor & $\begin{array}{c}\text { Subt otal } \\
\text { Btu/hr }\end{array}$ \\
\hline 102 Elect. vault & $8 \times 12$ & & & 64 & & 96 & $\begin{array}{r}1990 \\
192\end{array}$ & & 2182 \\
\hline 103 Storage & $12 \times 12$ & 20 & 30 & 96 & & 1.44 & $\begin{array}{r}1260 \\
1560 \\
2980 \\
290\end{array}$ & & 6090 \\
\hline 104 Work Room & $20 \times 38$ & 60 & 110 & 460 & & 760 & $\begin{array}{r}3780 \\
5720 \\
1+260 \\
1520\end{array}$ & $10 \%$ & 27,800 \\
\hline $\begin{array}{l}107 \text { Work Room } \\
\text {. }\end{array}$ & $25 \times 14$ & 52 & 64 & 41.3 & & 350 & $\begin{array}{r}3280 \\
3330 \\
12800 \\
700\end{array}$ & & 20,110 \\
\hline $\begin{array}{l}108 \text { Womrn } \\
\text { toilet room }\end{array}$ & $13 \times 5$ & & & 54 & & 6.5 & $\begin{array}{r}1675 \\
130\end{array}$ & & 1805 \\
\hline $\begin{array}{l}110 \text { Ninen } \\
\text { loilet room }\end{array}$ & $13 \times 5$ & & & 54 & & 65 & $\begin{array}{r}1675 \\
130\end{array}$ & & 1805 \\
\hline $\begin{array}{l}201 \text { Mien } \\
\text { toilnt room }\end{array}$ & $28 \times 12$ & 44 & & 468 & 366 & 366 & $\begin{array}{r}2770 \\
14500 \\
4020 \\
740\end{array}$ & $10 \%$ & 24,230 \\
\hline 202 Olservatory & $57 \times 35$ & 70 & 1360 & 550 & & 2000 & $\begin{array}{r}4.100 \\
70700 \\
17000 \\
23000\end{array}$ & $15 \%$ & 135,800 \\
\hline 203 Office & $20 \times 20$ & 40 & 70 & 4.30 & .100 & & $\begin{array}{r}2520 \\
3640 \\
13300 \\
1.400\end{array}$ & $10 \%$ & 26,440 \\
\hline 204 office & $13 \times 14$ & $40^{\circ}$ & 53 & 90 & 182 & & $\begin{array}{l}2520 \\
2760 \\
2790 \\
2000\end{array}$ & & 10,070 \\
\hline
\end{tabular}


Table B.3-1. Heating Load Calculation (Concluded)

\begin{tabular}{|c|c|c|c|c|c|c|c|c|c|}
\hline Room Name & $\begin{array}{c}\text { Dimension } \\
\mathrm{ft} \times \mathrm{ft}\end{array}$ & $\begin{array}{c}\text { Infiltra- } \\
\text { tion } \\
\mathrm{ft}\end{array}$ & $\begin{array}{l}\text { Glass } \\
\mathrm{ft}^{2}\end{array}$ & $\begin{array}{l}\text { Wall } \\
\mathrm{tt}^{2}\end{array}$ & $\begin{array}{l}\text { Roof } \\
\mathrm{ft}^{2}\end{array}$ & $\begin{array}{l}\text { Floor } \\
\mathrm{ft}^{2}\end{array}$ & Rtu/hr & Factor & $\begin{array}{l}\text { Subtotal } \\
\mathrm{Btu} / \mathrm{hr}\end{array}$ \\
\hline $\begin{array}{cc}205 \text { office } \\
-\end{array}$ & $17 \times 15$ & 20 & 53 & 135 & 255 & & $\begin{array}{l}1260 \\
2760 \\
1190 \\
2805\end{array}$ & & 11,015 \\
\hline 208 offics & $1.3 \times 11$ & 10 & 56 & 136 & $\begin{array}{l}\because \\
143\end{array}$ & & $\begin{array}{l}2 ! 201 \\
2910 \\
4230 \\
1.570\end{array}$ & & 11,230 \\
\hline 210 offlce & $12 \times 12$ & 20 . & 32 & .112 & 144 & & $\begin{array}{l}1260 \\
1660 \\
2470 \\
1585\end{array}$ & & 7975 \\
\hline 211 office & $12 \times 16$ & 40 & 48 & 204 & 192 & & $\begin{array}{l}2520 \\
3400 \\
63330 \\
2100\end{array}$ & & 14.360 \\
\hline 212 audio control & $4 \times 7$ & & & 48 & 28 & & $\begin{array}{l}1485 \\
3080\end{array}$ & - & 4565 \\
\hline 213 lobby & $36 \times 44$ & 154 & 470 & 550 & 1660 & 16600 & $\begin{array}{r}9700 \\
24400 \\
17050 \\
18300 \\
3350 \\
\end{array}$ & & 72,800 \\
\hline $\begin{array}{l}214 \text { women } \\
\text { toilet room }\end{array}$ & $28 \times 12$ & $\begin{array}{r}44 \\
.\end{array}$ & & 468 & 366 & 366 & $\begin{array}{r}2770 \\
1.1500 \\
4020 \\
740\end{array}$ & & 22.030 \\
\hline $\begin{array}{l}215 \text { janitor } \\
\text { closet }\end{array}$ & $5 \times 5$ & & & 45 & 25 & 25 & $\begin{array}{c}1345 \\
275 \\
50 \\
\\
\text { Totai }\end{array}$ & & $\frac{1670}{401,977}$ \\
\hline
\end{tabular}


Table B. 3-2. Cooling Load Calculation

Room 202 observatory:

Design conditions

Outside temp $-95^{\circ} \mathrm{F}$, inside temp $-80^{\circ} \mathrm{F}$, difference $-15^{\circ} \mathrm{F}$

Outside walls: (sq ft)

\begin{tabular}{|c|c|c|}
\hline Side & Glass & Net wall \\
\hline $\begin{array}{l}\text { North } \\
\text { West }\end{array}$ & $\begin{array}{r}150 \\
1200\end{array}$ & 450 \\
\hline
\end{tabular}

Cooling load: BTU/HR

Items

Sensible heat gain thru glass

150 sq. ft. $\times 23 \mathrm{Btu} / \mathrm{ft}^{2} / \mathrm{hr}$

$(22-3.5) \times 54 \times 140$
Sensible Latent

3,450

140,000
$3.5 \mathrm{ft}$ approx: shading solar heat gain approx $140 \mathrm{Btu} / \mathrm{ft}^{2} / \mathrm{hr}$ 4:00 pm July 21

Transmission gain

Walls $450 \mathrm{sq} f \mathrm{ft} .20$ (factor) $\quad 1,350$

$$
\mathrm{x} \text { is }(\Delta \mathrm{T})
$$

Roof $2000 \times .80 \times 15$

24,000

Internal heat gain:

People \& lights

People:

$$
\frac{\text { No. }}{40} \times \frac{\begin{array}{c}
\text { Sensible } \\
\text { factor }
\end{array}}{200} \times \frac{\begin{array}{c}
\text { Latent } \\
\text { factor }
\end{array}}{250}
$$

$$
8,000
$$

10,000

Lights: 5000 watts $\times 3.4$

Total

$$
\frac{17,000}{149,800}
$$$$
10,000
$$

Ventilation or infiltration

450 CFM $\times 1.08 \times 35=17,000$ Sensible

450 CFM $\times 1.08 \times \frac{35}{3}=5,700$ Latent

Total load $=149800+10,000+17,000+5,700=182 ; 500 \mathrm{Btu} / \mathrm{hr}$

$$
\text { or } \frac{182,500}{12,000} \approx 15 \text { tons }
$$


ed by multiplying a typical direct sunlight reading in Rapid City of 290 $\mathrm{Btu} / \mathrm{hr}-\mathrm{ft}^{2}$ by a geometrical factor and also multiplied by the percentage sunlight for the particular day. The geometrical factor was the scalar product of the normal to the collector surface with the sun's rays expressed as a function of tilt of the earth's axis, local latitude, slope of the roof, orientation of the building, slope of the collector with respect to the roof, day of the year and time of day. The geometric factor also includes the shading effect of adjacent collectors.

The model was run using the climatological data for 1971-1974. The results shown in Table B.3-3 are for a typical day using the average high and low temperatures for that month and assuming 100 percent sunshine. This total is multiplied by the average percentage sunshine for the month. This. method of approximation was checked by detailed hour-by-hour calculation using February 1973, when the storage temperature dropped to nearly $80^{\circ} \mathrm{F}$ every night, and October 1973, when the storage temperature rose to around $160^{\circ} \mathrm{F}$. In both cases the results were very close to the approximation; for February it was 3 percent low; for October the difference was less than 1 percent.

The percentage heating carried by the solar system is expected to be at least 53 percent since the atmospheric conditions at Mount Rushmore are more favorable than in Rapid City. Based on the current market price of $\$ 0.39$ per gallon for No. 2 fuel oil, the savings amounts to about $\$ 1,710$ of the $\$ 3,226$ worth of fuel consumed in FY 1975 .

Solar cooling calculations are based on 165,000 Btu/hr of heat delivered to the cooling units at $210^{\circ} \mathrm{F}$ from the collectors. The limiting conditions of ambient temperature, percentage sunshine and time of day under which the above criteria could be met were determined." The climatological 
Table B.3-3. Heating/Cooling Solar Contribution

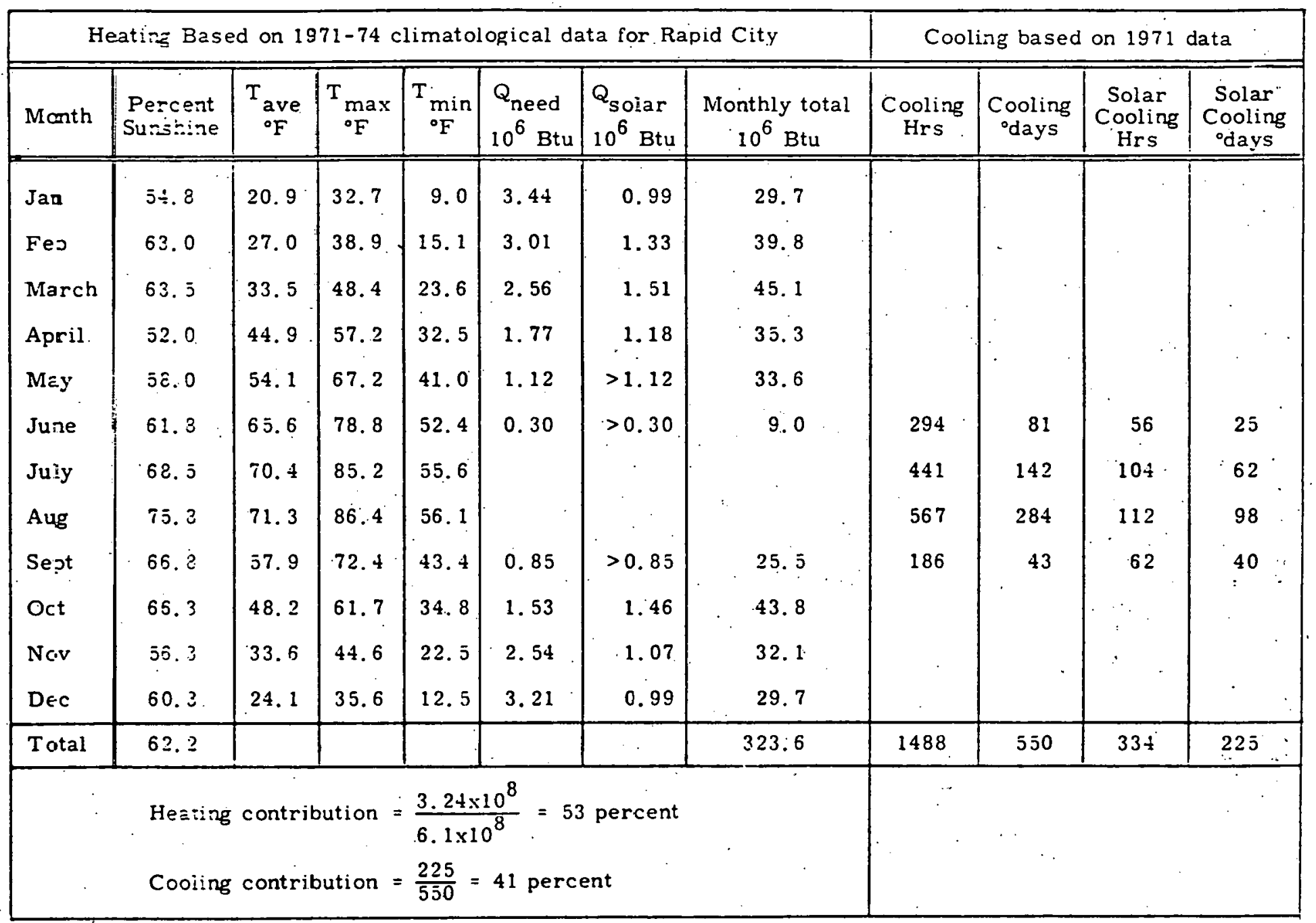


data of 1971 were then examined to determine the number of hours that the limiting conditions were exceeded when there was also a demand for cooling in the observatory. This is recorded in Table B. 3-3 as the number of solar hours of cooling. The total number of hours of cooling demand and the number of cooling degree days are also in that table.

The number of degree days when the solar absorption units were operating was found. The percentage of solar cooling was then figured by the ratio of solar degree days to cooling degree days.

$$
\text { Percent solar }=\frac{\text { Solar degree days }}{\text { Cooling degree days }} \times 100
$$

The savings from solar cooling can be approximated by assuming 334 hours of operation replacing a nine-ton conventional-type chiller with a coefficient of performance of 2.5. The savings is about $4230 \mathrm{~kW}-\mathrm{hr}$. At an estimated $3 \$$ per $k W-h r$, the saving amounts to about $\$ 127.00$ per year. 
7. Major problems encountered and resolutions thereto

One of the major problems is the air bubbles in the system. As explained in the operation of the system, constant venting with frequencies as much as once a week to prevent a buildup of temperatures: and pressures was necessary. The main pump was originally designed at the flow rate of $30 \mathrm{gpm}$. It was felt that the higher flow rate could solve the problem of pressure buildup or air bubbles problem. A larger pump was installed with the flow rate of approximately $48 \mathrm{gpm}$. This seemed to solve the air bubble problem. The frequency of air venting has drastically reduced.

Another problem encountered was one transformer was struck by lightening on August 14, 1978, Because of this, the main pump had lost the electric power supply so that the stagnant ethylene glycol solution in the collector loop was overheated and turned into steam. It took more than two weeks to repair the transformer, recharge the system and get it back into operation. This situation rarely happens.

The third major problem encountered was the thermosiphoning. On the last day of 1978, the ambient temperature was extremely. low and the cold antifreeze back-flowed into the main heat exchanger through a three way valve V4. Apparently there was a slight leakage through the three way valve V4 even though the three way valve was in a completely shut off position. The cold antifreeze back-flowed into the jacket of the main heat exchanger and froze the water inside the tube bundle. As a result, the cover plate of the main heat exchanger cracked about 5 to 6 inches; there were two cracked lines of about $3 / 4^{\prime \prime}$ in two tubes; and antifreeze began to leak out. The system was drained, the cracks on the tube bundle were brazed, and the cover plate was replaced. The whole system was down for about one month. A check valve was installed in the pipeline to prevent any future back-flow of antifreeze into the main heat exchanger. 
The last major problem is the control adjustment. In particular, the cam of all three way valves needs fine readjustment such that the sequence of operations will follow closely.

\section{Lessons learned and recommendations}

From the major problem of frequent air venting encountered in the operation of the system, the biggest cause may be the wrong locations of the inlet and outlet tubings to each solar panel. The roof on which the collector banks are mounted is sloping towards the east, such that each collector bank axis is tilting toward the east. The outlet tubings are on the lower end of each panel, thus any vapor lock or air bubbles may stay in the upper header tube of each panel and can never escape. This was a negligence on the part of collector supplier in shipping panels which were not according to shop drawings. A lesson learned here was that a close check of the panels before installation could have avoided the frequent air venting problems.

The second lesson learned from this project is that positive stop valves should be used instead of leaky three way valves. With positive stop valves the problem of thermosiphoning of cold antifreeze in to the main heat exchanger could have been avoided.

The third lesson learned is that some of the sensor locations should have been at different places to ensure more meaningful results. For example, the inlet and outlet water temperature sensors to collectors were placed too close to the three way valve, V4. When the water is not circulating in the collectors, the two sensors do not represent the true readings due to heat conduction from piping.

The fourth lesson learned is that the current control system is too complex. A slight mal-adjustment of the three way valve cam can easily 
cause malfunction of the operation sequence. A simpler control system is needed for the whole system such that any trouble-shooting will be much easier.

The last lesson learned from this project is a definite need of an onsite-monitor (OSM). During the last few months of operation, Mr. Val Fogle of Marshall Space Flight Center, NASA, Huntsville, Al (project monitor) helped install (on short loan basis) an on-site-monitoring system to the system. Through the OSM system, instant monitoring of various temperatures, flow rates, power requirement for various pumps and fans help understand and adjust the control sequence. Thus it enables us to know whether the system is in the right mode of operation.

9. The project manager, Dr. C. W. Chiang, of the South Dakota School of Mines has verified the following:

a. The solar system was installed per the enclosed as-built drawing.

b. The solar system met the acceptance test plan provisions.

c. The solar system met the interim performance criteria (NBSIR-1187) requirements. 